FIU Law Review

Volume 11

Number 2 Separation of Powers

Article 14

Spring 2016

\title{
Aging Disgracefully: Do Economic Laws Remain Rational in Spite of Changed Circumstances?
}

Johanna Talcott

Florida International University College of Law

Follow this and additional works at: https://ecollections.law.fiu.edu/lawreview

Part of the Constitutional Law Commons, Jurisprudence Commons, and the Law and Economics Commons

Online ISSN: 2643-7759

\section{Recommended Citation}

Johanna Talcott, Aging Disgracefully: Do Economic Laws Remain Rational in Spite of Changed

Circumstances?, 11 FIU L. Rev. 495 (2016).

DOI: https://dx.doi.org/10.25148/lawrev.11.2.14

This Comment is brought to you for free and open access by eCollections. It has been accepted for inclusion in FIU Law Review by an authorized editor of eCollections. For more information, please contact lisdavis@fiu.edu. 


\title{
Aging Disgracefully: Do Economic Laws Remain Rational in Spite of Changed Circumstances?
}

\author{
Johanna Talcott ${ }^{*}$
}

\section{INTRODUCTION}

Rational basis review-especially as it applies to economic regulation-needs a little more bite. Many scholars, practitioners, and judges have critiqued the Supreme Court's unfavorable treatment of economic liberties and the highly deferential nature of its lowest standard of review. ${ }^{1}$ Some have advocated for changes in the Court's approach to both, such as bulking up the scrutiny of rational basis review or eliminating distinctions between constitutional rights. ${ }^{2}$ While such calls are wellfounded and forceful, it is unlikely that there would be any substantial overhaul of nearly a century of firmly established constitutional jurisprudence. $^{3}$ An alternative method is that the courts can implement

J.D. candidate, May 2016, Florida International University College of Law; M.A., The Pennsylvania State University; B.A., University of Florida. I owe a tremendous debt of gratitude to Dominique Pando Bucci, Jeremy Talcott, and Bryan Wilson for their help with this endeavor.

1 See, e.g., Hettinga v. United States, 677 F.3d 471, 480-83 (D.C. Cir. 2012) (Brown, J., concurring); Patel v. Texas Dep't of Licensing and Reg., 469 S.W.3d 69, 98-99 (Tex. 2016) (Willett, J., concurring); Randy E. Barnett, Scrutiny Land, 106 Mich. L. ReV. 1479 (2008); Aaron Belzer, Putting the "Review" Back in Rational Basis Review, 41 W. ST. U. L. REV. 339 (2014); Marc P. Florman, The Harmless Pursuit of Happiness: Why "Rational Basis with Bite” Review Makes Sense for Challenges to Occupational Licenses, 58 LOY. L. REV. 721 (2012); Elizabeth Price Foley, Judicial Engagement, Written Constitutions, and the Value of Preservation: The Case of Individual Rights, 19 GEO. MASON L. REV. 909 (2012); Jessica E. Hacker, The Return to Lochnerism? The Revival of Economic Liberties from David to Goliath, 52 DePAul L. REV. 675 (2002); Clark Neily, No Such Thing: Litigating Under the Rational Basis Test, 1 NYU J.L. \& LIBERTY 898 (2005); Note, Resurrecting Economic Rights: The Doctrine of Economic Due Process Reconsidered, 103 HARV. L. REV. 1363 (1990); Austin Raynor, Economic Liberty and the Second-Order Rational Basis Test, 99 Va. L. Rev. 1065 (2013); Timothy Sandefur, Equality of Opportunity in the Regulatory Age: Why Yesterday's Rationality Review Isn't Enough, 24 N. ILL. U. L. REV. 457 (2004); Timothy Sandefur, The Right to Earn a Living, 6 CHAP. L. REV. 207 (2003); Neelum J. Wadhwani, Rational Reviews, Irrational Results, 84 TEX. L. REV. 801 (2006).

2 Some scholars have advocated for shifting the burden of proof back onto the government in rational basis review cases. See, e.g., Belzer, supra note 1, at 373 (proposing a "rationale review standard" for all nonsuspect class equal protection challenges, in which a successful prima facie case of an inappropriate classification would shift the burden on the government to justify the rationale behind the classification); Foley, supra note 1, at 927 (advocating for a return to the "old-school rational basis review" utilized by the pre-New Deal Supreme Court, which required the government to "prove a close fit between the means chosen and the purpose of the law"). Cf. Barnett, supra note 1, at 1499-1500 (advocating for elimination of the fundamental/non-fundamental rights dichotomy under due process in favor of a "presumption of liberty" that is generally rebuttable by the government).

3 See Caleb Nelson, Stare Decisis and Demonstrably Erroneous Precedents, 87 VA. L. REV. 1, 
minor doctrinal approaches, which comport with existing Supreme Court jurisprudence, but incrementally shift the law towards strengthened judicial scrutiny and greater preservation of economic liberty - sort of a "rational basis review with nibble." One such modest approach is the changed circumstances doctrine. ${ }^{5}$

When courts adjudicate legislation that impacts economic liberty, the applicable level of scrutiny, rational basis review, requires only that the government articulate a legitimate government interest (and if not, the court can even conceive of one) and assert that the law is a rationally related means of achieving that interest. ${ }^{6}$ Challenged legislation is afforded an extremely strong presumption of constitutionality and the courts have no obligation to conduct any fact-finding whatsoever into the rationality of the government's actions. ${ }^{7}$ In order to prevail, a challenger must essentially prove that every conceivable reason that the legislature may have had in passing the legislation is irrational. $^{8}$ In practice, this is a nearly insurmountable task. ${ }^{9}$ For example, the Supreme Court sided with the plaintiffs in only ten out of one hundred rational basis review cases between 1973 and $1996 .{ }^{10}$ By the Court's logic, all of those challenged laws were constitutionally rational.

But does a law remain rational indefinitely? Given the rapid clip of social and technological change - and the notorious lag of government-

1-4 (2001); see also Foley, supra note 1, at 927.

4 The author cannot locate any other instances of this phrase being used, but it seems an appropriate descriptor for an approach that does not substantively disrupt established law or doctrine and applies only in a relatively narrow range of cases.

5 See discussion infra pages 506-523.

6 See, e.g., FCC v. Beach Commc'ns, Inc., 508 U.S. 307, 313-15 (1993); Heller v. Doe, 509 U.S. 312, 319-20 (1993). In equal protection cases, the Court applies rational basis review in challenges to legislation that distinguishes between economic or social classes (nonsuspect classes). Strict scrutiny is reserved for legislation that distinguishes between suspect classes (race, national origin, and alienage) or burdens a fundamental right, and intermediate scrutiny for legislation that distinguishes between quasisuspect classes (gender, illegitimacy). In substantive due process cases, the Supreme Court bifurcates individual liberties into fundamental and non-fundamental rights. Fundamental rights are those which are "objectively, deeply rooted in this Nation's history and tradition, and implicit in the concept of ordered liberty, such that neither liberty nor justice would exist if they were sacrificed." Washington v. Glucksberg, 521 U.S. 702, 720-21 (1997).

7 Beach Commc'ns, 508 U.S. at 315 ("[A] legislative choice is not subject to courtroom factfinding and may be based on rational speculation unsupported by evidence or empirical data.").

8 Heller, 509 U.S. at 320 ("A statute is presumed constitutional and the burden is on the one attacking the legislative arrangement to negative every conceivable basis which might support it.") (citations and quotations omitted).

9 See Gerald Gunther, Foreword: In Search of Evolving Doctrine on a Changing Court: A Model for a Newer Equal Protection, 86 HARV. L. REV. 1, 8 (1972) (describing rational basis review as "minimal scrutiny in theory and virtually none in fact").

10 Robert C. Farrell, Successful Rational Basis Claims in the Supreme Court from the 1971 Term Through Romer v. Evans, 32 IND. L. REV. 357, 416 (1999). 
laws and regulations risk becoming outdated as the factual circumstances that justified their enactment begin to disappear. ${ }^{11}$ Governments prudently leave many outdated laws unenforced, such as the Pennsylvania statute that requires motorists to stop every mile on rural roads to send up rocket signals, the Michigan law that prohibits a married woman from going to the hair stylist without her husband's permission, or the ban on Sunday yoyoing that is on the books in a handful of states. ${ }^{12}$

With economic regulation, however, governments may continue to enforce laws even after drastic changes in factual circumstances render them obsolete. This might be the case, for example, when some new product, business model, or innovation emerges that the legislature could not have anticipated and did not account for in the existing regulatory framework. ${ }^{13}$ Established businesses, which have often invested considerable costs to operate under existing regulations, are understandably frustrated when their competitors are not bound by the same restrictive and expensive rules. ${ }^{14}$ Governments often respond by continuing to enforce the outdated regulations, or requiring indirect competitors to comply with existing regulations, even when doing so verges on the absurd. ${ }^{15}$

11 A cursory Google News search suggests that this is a fairly common feature throughout the world. See, e.g., Kathleen Gray, Michigan Laws in Crosshairs: Don't Cuss, Dye Chicks, USA TODAY (Mar. 24, 2015), www.usatoday.com/story/news/nation/2015/03/24/mich-laws-crosshairs-cuss-dye-chic ks/70404872; Tiffany Owens, Ala. Legislators Seek to Repeal Antiquated Laws, Cullman TiMES (Mar. 17, 2015), www.cullmantimes.com/news/ala-legislators-seek-to-repeal-antiquated-laws/article_a0619e4 2-cc47-11e4-91d5-af3fc27c9839.html; Jane Walsh, Ireland to Revoke 5,782 Outdated Laws, IRISH CENT. (Mar. 17, 2015), www.irishcentral.com/news/Ireland-to-revoke-5782-outdated-laws.html.

12 Stephanie Morrow, Top Craziest Laws Still on the Books, LEGAL ZoOM (Oct. 2009), www.legalzoom.com/articles/top-craziest-laws-still-on-the-books.

13 See Erica Taschler, A Crumbling Monopoly: The Rise of Uber and the Taxis Industry's Struggle to Survive, LOY. SCH L.: NEWS AND VIEWS (June 2015), www.luc.edu/media/lucedu/law/cen ters/antitrust/pdfs/publications/newsviews/Erica\%20Taschler $\% 20 \mathrm{New} \% 20 \% 20 \mathrm{Views} \% 20 \mathrm{With} \% 20$ Edit s\%20\%20Footnotes.pdf.

14 See $i d$. The government shares in the frustration when businesses find ways to lawfully circumvent the rules. See, e.g., Hettinga v. United States, 677 F.3d 471 (D.C. Cir. 2012); see also Dan Morgan, Sarah Cohen \& Gilbert M. Gaul, Dairy Industry Crushed Innovator Who Bested Price-Control System, WASH. PoST (Dec. 10, 2006), www.washingtonpost.com/wpdyn/content/article/2006/12/09/AR 2006120900925.html.

15 For example, one rule in an arcane web of Pennsylvania funeral industry regulations prohibits the serving of food or intoxicating beverages at a funeral home. The Third Circuit upheld the regulation, which dated back to the fifties. Heffner v. Murphy, 745 F.3d 56, 86 (3d Cir. 2014), cert. denied, 135 S. Ct. 220 (2014); see also Patel v. Texas Dep't of Licensing and Reg., 469 S.W.3d 69, 73-74 (Tex. 2016) (evaluating a requirement for eyebrow threaders to obtain expensive and time-consuming cosmetologist licenses). Cf. N.C. State Bd. of Dental Exam'rs v. FTC, 135 S. Ct. 1101 (2015) (involving a prohibition against non-dentists from performing simple teeth whitening procedures). Unfortunately, governments seldom respond to these conflicts by lifting the burdensome regulations for everyone. One recent example is the dispute in Austin, Texas, over Uber and Lyft refusing to abide by background check requirements imposed on taxi drivers. The popular ride-sharing services ultimately departed the city. See Jared Meyer, What Elizabeth Warren Gets Wrong About Uber, REASON (May 23, 2016), www.reason.com/archives/2016/05/23/what-elizabeth-warren-gets-wrong-about-u; see also J.D. Tuccille, 
The Supreme Court contemplated that factual circumstances could change enough to render continued enforcement of a law irrational. In the seminal case United States v. Carolene Products, the Court was clear that "the constitutionality of a statute predicated upon the existence of a particular state of facts may be challenged by showing to the court that those facts have ceased to exist." 16 This changed circumstances doctrine requires courts to evaluate the rationality of a law with regard to the objective factual circumstances existing when the law is challenged, rather than when it was enacted. The Court never overruled Carolene's mandate ${ }^{17}$ and consistently gives weight to changed factual circumstances in other areas of constitutional law. ${ }^{18}$ Nevertheless, lower courts have diverged over whether and how to account for changed factual circumstances in rational basis review. ${ }^{19}$ Those courts that have deviated from Carolene's rule have focused on practical concerns and a perceived ambivalence from the Supreme Court on the issue. ${ }^{20}$

This comment argues that courts that have abandoned the changed circumstances doctrine in rational basis review have gotten it wrong. A law must pass constitutional muster not only when enacted but also when enforced-holding otherwise could effectively put an expiration date on constitutional rights. The changed circumstances doctrine is an essential component of rational basis review that, if employed consistently, serves as a much-needed judicial limit on economic regulation. This comment first reviews the history of the Supreme Court's development of rational basis review and declining protections for economic liberty. It then examines

After Winning Regulatory Battle Against Ride-Sharing Firms, Austin Turns to Black Market and Deregulation, REASON (May 31, 2016), www.reason.com/archives/2016/05/31/after-winning-regulatorybattle-against.

16 United States v. Carolene Prods. Co., 304 U.S. 144, 153 (1938).

17 The Supreme Court has never had the opportunity to directly address the issue of whether a law's constitutionality must be evaluated with regard to the facts in existence at the time the law is challenged - all of the one hundred and fifty rational basis review cases to reach the Supreme Court in the seventy-eight years since Carolene were challenges to recently enacted legislation. Petition for Writ of Certiorari at 14, Heffner v. Murphy, 135 S. Ct. 220 (2014) (No. 14-53), 2014 WL 3530761, at *14 [hereinafter Heffner v. Murphy Petition].

18 E.g., Grutter v. Bollinger, 539 U.S. 306 (2003); Shelby Cnty. v. Holder, 133 S. Ct. 2612 (2013).

19 Courts' analyses of changed circumstances have cut across several areas of constitutional law and all levels of judicial scrutiny. See, e.g., Allison Orr Larsen, Do Laws Have a Constitutional Shelf Life?, 94 Tex. L. Rev. 59 (2015); Maria Ponomarenko, Changed Circumstances and Judicial Review, 89 N.Y.U. L. REV. 1419 (2014); Sean G. Williamson, Contemporary Contextual Analysis: Accounting for Changed Factual Conditions Under the Equal Protection Clause, 17 U. PA. J. ConST. L. 591 (2014).

20 E.g., Burlington N. R.R. Co. v. Dep't of Pub. Serv. Reg., 763 F.2d 1106 (9th Cir. 1985) (finding that circumstances had not sufficiently changed to make regulation unconstitutional); Dias v. City \& Cnty. of Denver, 567 F.3d 1169 (10th Cir. 2009) (permitting a due process claim to proceed on a theory of changed circumstances). 
how the Supreme Court and other courts have approached changed factual circumstances and their impact on a law's constitutionality. The final section advances arguments for why accounting for changed circumstances is, and should remain, a basic part of the rational basis review, as well as how the changed circumstances doctrine could benefit economic liberty.

\section{THE RISE OF RATIONAL BASIS REVIEW AND FALL OF ECONOMIC LIBERTY}

Depending on one's political or philosophical proclivities, rational basis review and the Court's hostility towards economic liberty represent either a complete derailing of fundamental constitutional principles ${ }^{21}$ or the proper preservation of legislative power and democracy. ${ }^{22}$ Through whichever lens this history is perceived, there can be little dispute that in modern practice, judicial review for economic regulation has become so highly deferential that it operates as little more than a "rubber stamp of approval" for government action. ${ }^{23}$

The earliest roots of rational basis review lie in the English common law, which prohibited arbitrary and unreasonable government actions and required any intrusions into a citizen's liberty to be justified. ${ }^{24}$ This concept was imported into American constitutional law to preserve life, liberty, and property, primarily with regard to procedural due process. ${ }^{25}$ By the end of the nineteenth century, the Court began to evaluate legislation for its impact on substantive due process, and struggled with ascertaining which legislative actions fell within and beyond the police power of the states. ${ }^{26}$ The tool the Court developed to make this determination was a means-end arbitrariness analysis, of which one of the earliest and clearest articulations is found in Mugler v. Kansas:

If . . . a statute purporting to have been enacted to protect the public health, the public morals, or the public safety, has no real or substantial relation to those objects, or is a palpable invasion of rights secured by the fundamental law, it is the duty of the courts to so adjudge, and

21 See sources cited supra note 1.

22 See, e.g., Howard Gilman, The CONSTITUTION BEsIEgED: THE Rise AND DEMISE OF LOCHNER ERA POLICE POWERS JURISPRUDENCE 1-18 (1993).

23 See, e.g., Richard B. Sapphire, Equal Protection, Rational Basis Review, and the Impact of Cleburne Living Center, Inc., 88 KY. L.J. 591, 607 (2000) (citing several cases and articles referring to the "softness" and "leniency" of rational basis review).

24 Jeffrey D. Jackson, Putting Rationality Back into the Rational Basis Test: Saving Substantive Due Process and Redeeming the Promise of the Ninth Amendment, 45 U. RICH. L. REV. 491, 499-501 (2011) (citing Blackstone's Commentaries).

25 Id.

26 Id. at 502-11 (describing a number of early Due Process Clause cases). 
thereby give effect to the Constitution. ${ }^{27}$

In earlier cases, the legislation under review was granted-either explicitly or implicitly - a presumption of constitutionality, and the challenger bore the burden of proving it unconstitutional. ${ }^{28}$ Challengers were largely unsuccessful: Under this general scheme, the Supreme Court upheld as constitutional ninety-two of the ninety-eight substantive social and economic acts of legislation that came before it. ${ }^{29}$

The infamous Supreme Court case Lochner v. New York implemented only a minor change in the existing means-end review calculus, but its impact and significance have reverberated broadly. ${ }^{30}$ The Court's development of the highly deferential rational basis review that exists today reflects an explicit rejection of the type of searching scrutiny utilized in Lochner and its progeny, as well as Lochner's protection of economic liberty. The Lochner era is often characterized as a time when an overzealous, activist Supreme Court sought to stymie progressive government action by striking down laws and regulations with which it disagreed under the guise of an unenumerated right to contract. ${ }^{31} \mathrm{~A}$ far more accurate characterization is that the Court variously validated and invalidated economic regulations during this time period by conducting careful factual inquiries in an effort to satisfy the established means-end arbitrariness test. ${ }^{32}$ Understood properly, Lochner serves as an example of

27 Mugler v. Kansas, 123 U.S. 623, 661-62 (1887).

28 Jackson, supra note 24, at 510.

29 Id. at 508.

30 See DAVID E. Bernstein, ReHABILITATING LOCHNER 1-8 (2011) (describing the widespread, but misplaced, derision of Lochner by judges, scholars, journalists, and even President Obama).

31 See id., at 1-8; see also Neily, supra note 1, at 903. This strong disapproval of Lochner has enjoyed uniquely broad overlap between liberals and conservatives, albeit for largely different reasons. See Thomas B. Colby \& Peter J. Smith, The Return of Lochner, 100 CoRnell L. REV. 527, 529 (2015). At the core of most Lochner criticisms is the perception of an overreaching, unrestrained judiciary. Id. For liberals, this hinges on the perceptions of the Court's unseemly protection of a right - the right to contract - that should not warrant constitutional protection and of the Court's inappropriate supplanting of the legislature's wisdom and judgment with its own theoretical preferences. Id. Conservatives, although far more sympathetic to economic rights, are generally opposed to the protection of rights that are not specifically enumerated in the text of the Constitution. Id. This conservative preference for judicial restraint is largely in response to the Warren and Burger Courts' willingness to identify and protect unenumerated rights. Id. at 528. The conservative angle in the anti-Lochner orthodoxy is evolving, however, as it has become clear that substantial judicial deference has led to the virtual elimination of fundamental constitutional rights - most severely economic liberty. Id. at 531 .

32 See BERnSteIn, supra note 30, at 1-8. In fact, the Supreme Court decided ninety-seven cases regarding substantive due process between 1913 and 1920, and in a meager five of those cases was the legislation overturned. Jackson, supra note 24, at 513. Four cases from the Lochner era dealing with minimum wage and hour laws-Lochner v. City of New York, 198 U.S. 45 (1905), Muller v. Oregon, 208 U.S. 412 (1908), Adkins v. Children's Hosp. of Dist. of Colum., 261 U.S. 525 (1923), and W. Coast Hotel Co. v. Parrish, 300 U.S. 379 (1937)—particularly illustrate the Court's lack of consistency (i.e., the Lochner Court did not strike down every progressive economic regulation that came before it, as is 
the type of thorough factual analysis that courts undertake when considering challenges based on changed circumstances.

The Lochner facts are straightforward-the New York Bakeshop Act placed a number of regulations on bakeries, including strict limits on the number of hours that employees could voluntarily work. ${ }^{33}$ As it had previously done, the Court recognized that the statute interfered with the right to contract between the employer and employees, but that the state could place reasonable limits upon that right. ${ }^{34}$ Significantly, the Lochner Court changed its approach to due process analysis and implicitly shifted the burden onto the government to prove that the interference was a reasonable exercise of the police power. ${ }^{35}$

The state proffered a number of public health and safety reasons for limiting the number of hours that bakers may work, such as preventing fatigue, limiting flour inhalation, and ensuring the cleanliness of bakers and their products. ${ }^{36}$ The Court looked at each alleged justification with a skeptical eye and found that the limitations on worker's hours made little sense in light of the numerous other rules that regulated the bakeshop facilities themselves. ${ }^{37}$ Lochner should not be characterized as a wholesale dismissal of legislation on the sole basis that it impeded the right to contract. ${ }^{38}$ The Court simply found-through thoughtful factual inquirythat the hourly limitations did not actually further the government's purported objectives and therefore exceeded the power of the state to infringe upon the right to contract. ${ }^{39}$

so often suggested).

33 Lochner, 198 U.S. at 53. Bakers were prohibited from working more than ten hours in a day, and more than sixty hours in a week. $I d$.

34 Id. The treatment of something like the liberty of contract as a fundamental right first appeared in Allgeyer v. Louisiana, 165 U.S. 578, 590-93 (1897) (striking down a statute that prohibited a Louisiana citizen from contracting for marine insurance with a New York insurance company that was not licensed to do business in the state). During this time the Supreme Court recognized a very broad definition of liberty under the Due Process Clause. Jackson, supra note 24, at 510.

$35 I d$. at 511.

36 Lochner, 198 U.S. at 60-63.

37 Id. at $62-63$. The Court noted that one inference from the government's justifications for the bakeshop laws was that one could draw a distinction between the healthfulness of bread baked by a person who works only ten hours a day and that of bread baked by a person who works eleven hours a day. Id. The bread baked by the latter-according to the government's logic-was no longer healthful or fit to be sold to the public. Id. The Court found this distinction to be "unreasonable and entirely arbitrary." Id.

38 Neily, supra note 1, at 903.

$39 I d$. The Court was also appropriately suspicious of the legislative intent behind the bakeshop laws. Lochner, 198 U.S. at 62 ("The connection, if any exists, is too shadowy and thin to build any argument for the interference of the legislature."); $i d$. at 63 ("It gives rise to at least a suspicion that there was some other motive dominating the legislature than the purpose to serve the public health or welfare."). The union-backed Bakeshop Act was passed in 1895. David E. Bernstein, Lochner v. New York: A Centennial Retrospective, 83 WASH. U. L.Q. 1469, 1482 (2005). The historical evidence 
In the following thirty years or so, the Court used the approach in Lochner to both strike down and uphold wage and hour restrictions. ${ }^{40}$ But by West Coast Hotel Co. v. Parrish, ${ }^{41}$ the Court made clear that it was no longer willing to meaningfully protect any economic right--let alone the unenumerated right to contract-from government interference. ${ }^{42}$ Considering a minimum wage regulation for women and children, the Court determined that the law was a reasonable, non-arbitrary, and nondiscriminatory means of regulating the relationships between employers and the employed. ${ }^{43}$ In this final case of the Lochner era, the Court expressed its vision of the proper role of the judiciary with regard to economic regulation: The courts are "both incompetent and unauthorized to deal" with assessing the "adequacy or practicability of the law enacted." Therefore, the Court maintained, the legislature was the only appropriate arbiter of the wisdom or necessity of economic regulations, and "every plausible presumption is in favor of [their] validity."

The presumption of constitutionality for economic regulation became firmly established in United States $v$. Carolene Products. ${ }^{46}$ The Court

indicates that the Bakeshop Act was passed primarily as an effort to protect large, unionized bakeries against competition from small, immigrant enterprises. Id. at 1476. The growing number of Italian, French, and Jewish immigrant bakeries posed a substantial business threat because they were able to produce comparable products at lower prices. Id. This was primarily because the immigrants set up oldfashioned bakeries in the basements of cheap tenement buildings and their employees were on call nearly twenty-four hours a day, often sleeping on the floors of the bakery. Id. at 1477.

40 Just three years after Lochner, the Supreme Court reached the opposite result for similar legislation that applied only to women. Using the same Lochner analysis in Muller v. Oregon, the Court found that minimum wage and weekly hour limits for women in certain industrial-type workplaces, like laundries and factories, were constitutional. 208 U.S. 412, 421 (1908). The Court considered a number of scientific and sociological studies about the supposed limited physical abilities of women and potential injurious effects of long working hours on the health of women and their offspring and found that the state provided enough evidence to show that the regulations furthered the state's legitimate interest in protecting women's physical well-being. Id. at 420. Fifteen years after Muller, the Supreme Court invalidated a similar law fixing the minimum wage for women and children in the District of Columbia. In Adkins v. Children's Hospital of District of Columbia, the Court emphasized the passing of the Nineteenth Amendment, which granted women the right to vote, as an indication that the "ancient inequality of the sexes ... has continued with diminishing intensity." 261 U.S. 525, 552 (1923). The Court no longer accepted the notion that adult women should be subjected to laws and regulations that restricted their right to contract when the same restrictions could not be imposed upon adult men under similar circumstances. Id. Minimum wage and hour regulations may have imposed permissible restrictions on women's liberty of contract at a time when women were essentially second-class citizens, but any rationality disappeared once other rights and responsibilities of women were clearly established. Id. at 553 .

41 W. Coast Hotel Co. v. Parrish, 300 U.S. 379 (1937).

42 Id. at 392.

43 Id. at 397.

44 Id. at 398 (quoting Nebbia v. New York, 291 U.S. 502, 537-38 (1934)).

45 Id.

46 United States v. Carolene Prods. Co., 304 U.S. 144 (1938). 
acknowledged that a challenger may produce evidence to overcome the presumption, but maintained that where the propriety of legislation is "at least debatable," the dispute should be resolved in favor of the government. ${ }^{47}$ The Court tucked into the famous "Footnote Four" the foundation for the tiered approach to judicial constitutional review. ${ }^{48}$ Carolene's footnote is recognized for enabling the Court to serve as a champion of civil rights by creating heightened judicial scrutiny for legislation "affecting discrete and insular minorities." 49 The footnote also had the effect of relegating economic liberty to a lower echelon of constitutional importance- a status that persists today ${ }^{50}$ But, as detailed in the following section, Carolene is crucial precedent for the proposition that an economic regulation's constitutionality must be evaluated with regard to the factual circumstances that exist at the time the law is challenged.

In Williamson v. Lee Optical, the Court rendered the presumption of constitutionality virtually irrebuttable. ${ }^{51}$ The State of Oklahoma passed a number of laws regulating the visual care industry. ${ }^{52}$ The law made it illegal for opticians to take old lenses and place them into new frames, or use a device to measure the strength of an existing prescription to fabricate new lenses, unless the wearer first visited a licensed ophthalmologist or optometrist to obtain a prescription. ${ }^{53}$ Not only did this require customers to take an additional, costly step before they were able to upgrade their outdated or broken frames, but it substantially reduced business for opticians while preserving a virtual monopoly for ophthalmologists. ${ }^{54}$

The district court in Williamson v. Lee Optical undertook a thorough and searching inquiry into the effects and apparent motivation of the legislature in enacting the regulations and found that they bore no rational relationship to the government's proffered purpose of protecting the public welfare, health, and safety. ${ }^{55}$ But the Supreme Court reversed, establishing

$47 \quad I d$. at 154.

48 Id. at $152-153$ n. 4 .

49 See Felix Gilman, The Famous Footnote Four: A History of the Carolene Products Footnote, 46 S. TEX. L. REV. 163, 165-67 (2004).

50 Carolene Prods., 304 U.S. at 152-53 n.4. Carolene is far less known for its subsequent history and the dictum that would be later used to strike down the same legislation that Carolene upheld. See Milnot Co. v. Richardson, 350 F. Supp. 221 (S.D. Ill. 1972).

51 See Williamson v. Lee Optical of Okla. Inc., 348 U.S. 483 (1955).

52 Id. at 486

53 Id.

54 Randy E. Barnett, Keynote Remarks: Judicial Engagement Through the Lens of Lee Optical, 19 GEO. MASON L. REV. 845 (2012) (describing the historical circumstances surrounding Williamson v. Lee Optical, including the protectionist motives behind many of Louisiana's regulations of the visual care industry).

55 Lee Optical of Okla., Inc. v. Williamson, 120 F. Supp. 128 (W.D. Okla. 1954), aff'd in part, rev'd in part sub nom., Williamson v. Lee Optical of Okla. Inc., 348 U.S. 483 (1955). The district court 
the "rubber stamp" rational basis review that survives today. ${ }^{56}$ The Court determined that a law would be upheld as long as the government might have had any conceivable rationale for enacting the legislation as a way to correct a perceived evil. ${ }^{57}$ Although the plaintiff had convincingly negated all of the state's alleged rationales for enacting the laws, the Supreme Court helpfully hypothesized several additional reasons that the government had never even suggested. ${ }^{58}$ If rational basis review was not deferential enough, the Court was now practically joining the government's legal team.

A few Supreme Court decisions since Williamson v. Lee Optical have affirmed and further refined this extremely deferential version of rational basis review-virtually refining the test out of existence. In modern rational basis review, the government is relieved of any obligation to prove that the legislative means actually further their purported ends. And the courts have no duty to conduct any meaningful factual analysis into the rationality of economic regulations. ${ }^{59}$

When it comes to non-economic rights and non-suspect classes, the Supreme Court has not always applied rational basis review consistently. Some modern cases, in which the Court invalidated legislation under rational basis review, have stirred up questions about how rational basis review is applied and given some hope to those who wish for a more

found that an exemption for the sellers of ready-to-wear lenses, in particular, completely undermined the state's assertion that the measures would protect eyewear consumers. Id. at 138 ("The legislature must not blow hot and cold!'). The court held that the law violated both the Due Process and Equal Protection Clauses of the Fourteenth Amendment. Id. at 143.

56 Williamson, 348 U.S. at 488.

57 Id. ("It is enough that there is an evil at hand for correction, and that it might be thought that the particular legislative measure was a rational way to correct it.").

58 Id. at 487 ("The legislature might have concluded that the frequency of occasions when a prescription is necessary was sufficient to justify this regulation of the fitting of eyeglasses. Likewise, when it is necessary to duplicate a lens, a written prescription may or may not be necessary. But the legislature might have concluded that one was needed often enough to require one in every case. Or the legislature may have concluded that eye examinations were so critical, not only for correction of vision but also for detection of latent ailments or diseases, that every change in frames and every duplication of a lens should be accompanied by a prescription from a medical expert.").

59 See FCC v. Beach Commc'ns, Inc., 508 U.S. 307, 315 (1993) (“[A] legislative choice is not subject to courtroom fact-finding and may be based on rational speculation unsupported by evidence or empirical data."); Heller v. Doe by Doe, 509 U.S. 312, 320 (1993) (“A State . . has no obligation to produce evidence to sustain the rationality of a statutory classification."); Minnesota v. Clover Leaf Creamery Co., 449 U.S. 456, 464 (1981) ("Where there was evidence before the legislature reasonably supporting the classification, litigants may not procure invalidation of the legislation merely by tendering evidence in court that the legislature was mistaken."); R.R. Retirement Bd. v. Fritz, 449 U.S. 166, 179 (1980) (Under rational basis review, "it is constitutionally irrelevant [what] reasoning in fact underlay the legislative decision.") (quoting Flemming v. Nestor, 363 U.S. 603, 612 (1960)). But see Schware v. Bd. of Bar. Exam'rs, 353 U.S. 232 (holding that the state's denial of a bar application for prior arrest record, use of aliases, and past Communist Party membership was not rationally related to the applicant's current fitness to practice law and violated the Due Process Clause). 
searching and exacting judiciary. ${ }^{60}$ What many of these cases have in common is that the Court identified discriminatory animus against a politically unfavored group as the pretextual motivation behind the government's alleged legitimate purposes. ${ }^{61}$ These cases did not involve economic regulations; however, they reveal that the Supreme Court has not completely renounced the idea that a challenger, armed with the right set of facts and circumstances, can still overcome the strong presumption of constitutionality that accompanies rational basis review.

A handful of recent decisions from lower federal courts and state courts of last resort have indicated an increased willingness to actually review the rationality of the factual justifications (or lack thereof) for economic regulations. Courts have invalidated restrictions on casket sales, ${ }^{62}$ hair braiding, ${ }^{63}$ eyebrow threading ${ }^{64}$ pest control, ${ }^{65}$ liquor sales ${ }^{66}$ shoeshine operations, ${ }^{67}$ and livery services. ${ }^{68}$ Whether the Supreme Court would ever

60 See, e.g., Lawrence v. Texas, 539 U.S. 558 (2003) (invalidating Texas anti-sodomy law); Romer v. Evans, 517 U.S. 620 (1996) (invalidating Colorado state constitutional amendment that banned anti-discrimination laws on the basis of sexual orientation); City of Cleburne, Tex. v. Cleburne Living Ctr., 473 U.S. 432 (1985) (invalidating city's ordinance excluding group homes for the intellectually disabled); Quinn v. Millsap, 491 U.S. 95 (1989) (invalidating state law requirement that party own real property in order to be appointed to government board); Allegheny Pittsburgh Coal Co. v. Cnty. Comm'n, 488 U.S. 336 (1989); Williams v. Vermont, 472 U.S. 14 (1985); Hooper v. Bernalillo Cnty. Assessor, 472 U.S. 612 (1985); Metropolitan Life Ins. v. Ward, 470 U.S. 869 (1985); Plyler v. Doe, 457 U.S. 202 (1982); Zobel v. Williams, 457 U.S. 55 (1982); U.S. Dep't of Agric. v. Moreno, 413 U.S. 528 (1973); see also Mathews v. Lucas, 427 U.S. 495, 510 (1976) (noting that rational basis review is not "toothless"). The scrutiny utilized in these cases has been dubbed "rational basis review with bite."

61 E.g., Lawrence, 539 U.S. at 583 (homosexuals); Cleburne, 473 U.S. at 446 (intellectually disabled individuals); Quinn, 491 U.S. at 107 (non-real property owners); Moreno, 413 U.S. at 534 (hippies). One reason for extending greater judicial protection to these groups is that they are likely to be politically powerless and "cannot themselves mandate the desired political responses" to eliminate legislation that negatively impacts them. Cleburne, 473 U.S. at 446.

62 See St. Joseph Abbey v. Castille, 712 F.3d 215 (5th Cir. 2013); Craigmiles v. Giles, 213 F.3d 220 (6th Cir. 2002).

63 See Brantley v. Kuntz, 98 F. Supp. 3d 884 (W.D. Tex. 2015); Clayton v. Steinagel, 885 F. Supp. 2d 1212 (D. Utah 2012); Cornwell v. Hamilton, 80 F. Supp. 2d 1101 (S.D. Cal. 1999). But see Bah v. Atty. Gen. of Tenn., 610 F. App’x 547 (6th Cir. 2015); Diwara v. State Bd. of Cosmetology, 852 A.2d 1279 (Pa. Commw. Ct. 2004).

64 See Patel v. Texas Dep't of Licensing and Reg., 469 S.W.3d 69 (Tex. 2016). But see JuStringz-Century III Mall v. Bureau of Prof'l and Occupational Affairs, State Bd. of Costmetology, 22 A.3d 298 (Pa. Commw. Ct. 2011).

65 See Merrifield v. Lockyer, 547 F.3d 978 (9th Cir. 2008).

66 See Maxwell's Pic-Pac, Inc. v. Dehner, 887 F. Supp. 2d 733 (W.D. Ky. 2012), aff'd in part and rev'd in part, Maxwell's Pic-Pac, Inc. v. Dehner, 739 F.3d 936 (6th Cir. 2014) (favorable equal protection claim reversed on appeal).

67 See Barry v. Brown, 710 F. Supp. 352, 355-56 (D.D.C. 1989).

68 See Santos v. City of Houston, 80 F. Supp. 601 (S.D. Tex. 1994); see also Bokhari v. Metro. Gov't, No. 3:11-00088, 2012 WL 162372 (M.D. Tenn. 2012). But see Speed's Auto Servs. v. City of Portland, No. 3:12-CV-738-AC, 2013 WL 1826141 (D. Or. 2012); Leib v. Hillsborough Cnty. Pub. 
be willing to scale back its deferential stance on economic regulation is open to speculation, but an emerging circuit split over whether naked economic protectionism, with nothing more, is a legitimate state interest could provide an opportunity for the Court to further define the limits of the government's power to interfere with economic liberties. ${ }^{69}$

What the cases in the preceding two paragraphs illustrate is that rational basis review - even in its highly deferential state-still entails drawing logical connections that are grounded in real-world, factual circumstances. The Court has never endorsed an approach that permits the government to produce "merely fanciful" justifications for economic regulation. $^{70}$ And as one district court noted: "Even the minimal rational basis test does not require the court to muse endlessly about [a] regulation's conceivable objectives nor to 'manufacture justifications' for its continued existence." ${ }^{71}$ With confidence that facts still matter in rational basis review, the following section considers what happens when facts change.

\section{Changed CiRCUMSTANCES IN CONSTITUTIONAL LAW}

The Supreme Court has consistently articulated the principle that laws can have a "constitutional shelf life." 72 In several areas of constitutional law, and at every level of judicial scrutiny, the Court has demonstrated that a law's constitutionality should be evaluated with regard to the factual circumstances in existence at the time the law is challenged. But in the seventy-eight years since Carolene, which established the modern, highly deferential rational basis review, the only rational basis review cases the Court has reviewed have involved recently enacted legislation. ${ }^{73}$ Thus, the Court has not yet had an opportunity to reaffirm and clarify the role of the changed circumstances doctrine in rational basis review. As a result, the lower courts have diverged over whether and how the changed circumstances doctrine should be applied in rational basis review cases. ${ }^{74}$

\footnotetext{
Transp. Comm'n, 558 F.3d 1201 (11th Cir. 2009).

69 See infra note 232.

70 Lee Optical of Okla., Inc. v. Williamson, 120 F. Supp. 128, 134 n.10 (W.D. Okla. 1954).

71 Brown, 710 F. Supp. at 356 (quoting Schlesinger v. Ballard, 419 U.S. 498, 520 (1975) (Brennan, J., dissenting)).

72 See Larsen, supra note 19, at 60 n.17.

73 See Heffner v. Murphy Petition, supra note 17, at*14. Of the 150 rational basis review cases that the Supreme Court decided since Carolene Products, all were challenges to recently enacted legislation. Id.

74 See, e.g., Heffner v. Murphy, 745 F.3d 56, 62 (3d Cir. 2014), cert. denied, 135 S. Ct. 220 (2014); Dias v. City \& Cnty. of Denver, 567 F.3d 1169 (10th Cir. 2009); Burlington N. R.R. Co. v. Dep't of Pub. Serv. Reg., 763 F.2d 1106 (9th Cir. 1985); Murillo v. Bambrick, 681 F.2d 898 (3d Cir. 1982); Jones v. Schneiderman, 888 F. Supp. 2d 421 (S.D.N.Y. 2012); Santos v. City of Houston, 80 F. Supp. 601 (S.D. Tex. 1994); Milnot Co. v. Richardson, 350 F. Supp. 221 (S.D. Ill. 1972); Peck v. Fink, 2 F.2d 912 (D.C. Cir. 1924); Colorado v. Albrecht, 358 P.2d 4 (Colo. 1960); Conner v. Cone, 235 So. 2d
} 


\section{The Changed Circumstances Doctrine Defined}

It is critical to first define precisely what the changed circumstances doctrine is and what it is not. The changed circumstances doctrine requires a court to evaluate the relevant factual circumstances (from the record or by judicial notice ${ }^{75}$ ) and their relation to a fixed constitutional principle to determine whether that principle was violated. ${ }^{76}$ This analytical approach utilizes the current standard of constitutional analysis at the time of the challenge - for example, an economic law must bear a rational relationship to a legitimate government purpose. The court applies the current standard to the relevant factual circumstances to establish legitimacy or illegitimacy, rationality or irrationality. ${ }^{77}$ The changed circumstances doctrine accounts for the possibility that the relevant factual circumstances could change in such a way as to cause a constitutional law to cross into unconstitutionality.

This is distinct from living constitutionalism, which presumes that constitutional rules can change in response to changes in the relevant factual or societal circumstances. ${ }^{78}$ Some Supreme Court decisions have used changed or changing circumstances - as evidenced by social values, ${ }^{79}$ sociological data, ${ }^{80}$ or foreign and international law $^{81}$ —as justifications for creating or altering existing constitutional rules. ${ }^{82}$ That is not the approach that is described or advocated here. ${ }^{83}$ While those same considerations

492 (Fla. 1970); Georgia S. \& Fla. R.R. v. Seven-Up Bottling Co. of Se. Ga., 175 So. 2 d 39 (Fla. 1965); Wegan v. Village of Lexington, 309 N.W.2d 273 (Minn. 1981); Caruso v. Aluminum Co. of America, 473 N.E.2d 818 (Ohio 1984).

75 See Larsen, supra note 19 , at 72.

76 See id. at 60-61; see also Williamson, supra note 19, at 604-05.

77 See Larsen, supra note 19, at 70-76, for an interesting discussion on the role of facts in judicial review. See also Donald Faigman, Constitutional Fictions: A Unified Theory of CONSTITUTIONAL FACTS (2008).

78 See Larsen, supra note 19, at 60-61.

79 See Lawrence v. Texas, 539 U.S. 558 (2003) (citing shifting attitudes toward homosexuality as justification for overruling Bowers v. Hardwick, 478 U.S. 186 (1986), which upheld anti-sodomy laws). Hinging constitutional rules on abstract social concepts can be problematic: such concepts are difficult, if not impossible, to define with any certainty and can change very quickly. See Williamson, supra note 19 , at 604-05.

80 See Brown v. Bd. of Educ., 347 U.S. 483 (1954) (citing sociological studies about the impacts of "separate but equal" education policies on black children as justification for overruling Plessy $v$. Ferguson, 163 U.S. 537 (1896)).

81 See Roper v. Simmons, 543 U.S. 551 (2005) (using international law to bolster arguments that the death penalty for seventeen-year-olds violated the Eighth Amendment and overruling Stanford $v$. Kentucky, 492 U.S. 361 (1989)); see also Lawrence v. Texas, 539 U.S. at 576 ("[T]he reasoning and holding in Bowers have been rejected elsewhere. . . O Other nations . . . have taken action consistent with an affirmation of the protected right of homosexual adults to engage in intimate, consensual conduct.").

82 See generally David A. STRAuss, THE Living Constitution 1-6 (2010).

83 This is by no means to suggest that the results of the cases cited supra notes 79-81 were incorrect or that the living Constitution method of analysis is unprincipled or wrong. Cases that utilize this approach are simply irrelevant to the changed circumstances doctrine and beyond the scope of this 
could be relevant in a changed circumstances analysis, lower courts are not at liberty to disturb binding Supreme Court constitutional precedent or define new expansions or limitations of constitutional rights. ${ }^{84}$ The only objective of the changed circumstances doctrine is to determine the constitutionality of the regulation at issue, within the existing constitutional precedential framework, but in light of the relevant factual circumstances that exist at the time the regulation is challenged.

Under the changed circumstances doctrine, a law's "shelf life" can be reached in one of two ways: the factual circumstances underlying the government's interests are temporary and cease to exist, or changes in factual circumstances sever the relationship between the government's interests and the means used to further them. ${ }^{85}$ In most rational basis review changed circumstances cases, it is generally the second part of this inquiry that is in dispute. With respect to economic regulation, the government virtually always asserts an interest in protecting the public health, safety, and welfare. ${ }^{86}$ Articulated generally, these are enduring state objectives that are unlikely to disappear over time and will always be considered a legitimate government interest. ${ }^{87}$ Thus, the question most open for challenge in economic changed circumstances cases is whether-in light of the factual circumstances that exist at the time of the challenge- the law is still rationally related to protecting the public health, safety, and welfare.

\section{The Changed Circumstances Doctrine and Rational Basis Review}

The changed circumstances doctrine has been a part of the Supreme Court's rational basis review jurisprudence since the early twentieth century. Justice Holmes recognized that unforeseen changes in the facts justifying a law might require its invalidation, even if it was valid when enacted. $^{88}$ Other Justices echoed this principle. "[A] police regulation,

comment. For more on the complex and fascinating debate about living constitutionalism versus originalism, see, for example, ANTONIn SCALIA, A MATTER OF INTERPRETATION: FEDERAL COURTS AND THE LAW 3-48 (1997); STRAUSS, supra note 82; Jack M. Balkin, Framework Originalism and the Living Constitution, 103 Nw. U. L. REV. 549 (2009); Lawrence Lessig, Understanding Changed Readings: Fidelity and Theory, 47 STAN. L. REV. 395 (1995).

84 Also beyond the scope of this Comment is a discussion of the tension between stare decisis and the originalist interpretative method. See Planned Parenthood of Se. Pa. v. Casey, 505 U.S. 833, 854-63 (1992); Nelson Lund, Stare Decisis and Originalism: Judicial Disengagement from the Supreme Court's Errors, 19 GEO. MASON L. REV. 1029 (2012). This Comment presumes, for the purposes of the changed circumstances doctrine, that existing constitutional rules and principles are valid and binding.

85 See Williamson, supra note 19 , at 606.

86 See generally Florman, supra note 1; Neily, supra note 1; Sandefur, Equality of Opportunity, supra note 1.

87 See generally id.

88 See Chastleton Corp. v. Sinclair, 264 U.S. 543, 547-48 (1924) ("A law depending upon the existence of an emergency or other certain state of facts to uphold it may cease to operate if the 
although valid when made," Justice Hughes explained, "may become, by reason of later events, arbitrary and confiscatory in operation." Justice Brandeis stated, "A statute valid as to one set of facts may be invalid as to another. A statute valid when enacted may become invalid by change in the conditions to which it applied." $" 90$

One of the clearest expressions of the changed circumstances doctrine comes from one of the most important economic cases in Supreme Court jurisprudence. ${ }^{91}$ In addition to setting the stage for tiered scrutiny and establishing the strong presumption of constitutionality for economic regulation, Carolene confirmed the Court's previous declarations that a rational law could become irrational over time. ${ }^{92}$ The Court explained that when a statute is justified by specific factual circumstances, it could be found unconstitutional once those factual circumstances no longer exist. ${ }^{93}$

The Carolene Court reviewed a conviction under the Filled Milk Act, a federal law that prohibited the interstate sale of milk with added vegetable or coconut oils. ${ }^{94}$ Noting that the law could be upheld "wholly on the presumption of constitutionality," the Court nevertheless reviewed the evidence provided by the government to support its prohibition. ${ }^{95}$ The government contended that filled milk was "generally injurious to the public health and facilitated fraud upon the public" because it did not have the same levels of vitamins found in whole milk products. ${ }^{96}$ Therefore, according to the government, there was a substantial risk that children might be fed the filled milk and deprived of nutrients essential to growth and development. ${ }^{97}$ The Filled Milk Act was easily upheld.

Carolene is much more well-known for its footnote than its subsequent history. ${ }^{98}$ After two losses at the Supreme Court, the Carolene Products

emergency ceases or the facts change even though valid when passed."). In Chastleton, the Supreme Court considered the constitutionality of a temporary, emergency rent control statute in the District of Columbia. When the legislature reenacted the law based only on a legislative finding that the emergency conditions were still present, Holmes declined to accept the government's "prophecy" and remanded for fact-finding on whether the emergency conditions still existed. Six months later, a lower court declared that the emergency had ended and invalidated the statute. See Peck v. Fink, 2 F.2d 912 (D.D.C. 1924).

89 Abie State Bank v. Weaver 282 U.S. 765, 772 (1931).

90 Nashville, C. \& St. L. R.R. v. Walters, 294 U.S. 405, 415 (1935) (footnote omitted).

91 See supra notes 46-50 and accompanying text.

92 See United States v. Carolene Prods. Co., 304 U.S. 144, 153 (1938); see also Milnot Co. v. Richardson, 350 F. Supp. 221 (S.D. Ill. 1972).

93 Carolene Prods., 304 U.S. at 153. The Court cited Chastleton Corporation v. Sinclair, 264 U.S. 543 (1924), to support the proposition. See supra note 88.

94 Carolene Prods., 304 U.S. at 146-47.

95 Id. at $148-49,49$ n.2.

96 Id. at 149 n.2, 150 n.3.

97 Id.

98 See generally Gilman, supra note 49; Geoffrey P. Miller, The True Story of Carolene Products, 
Company changed its name to the Milnot Company and continued to sell filled milk on an intrastate basis in the states where it was produced, so as to avoid prosecution under the Filled Milk Act. ${ }^{99}$ Twenty-eight years later, Milnot waged one more constitutional attack against the Filled Milk Act in federal district court. ${ }^{100}$ Milnot produced evidence that since 1944, a variety of imitation milk and dairy products-functionally indistinct from the product sold by Milnot--had emerged on the market, and the government permitted their distribution in interstate commerce. ${ }^{101}$ The government had contended in Carolene that prohibiting the sale of filled milk was targeted at correcting a very specific evil-preventing malnutrition in children from consuming nutritionally inferior imitation dairy products. ${ }^{102}$ Milnot now argued that the broad availability of those products at the time of the challenge severed any rational connection between preventing malnutrition in children and prohibiting Milnot's products. ${ }^{103}$ The court agreed that the government's continued enforcement of the Filled Milk Act against Milnot was irrational. ${ }^{104}$

The Tenth Circuit Court of Appeals also recognized the viability of the changed circumstances doctrine in reversing the dismissal of a substantive due process challenge to the city of Denver's pit bull ban. ${ }^{105}$ The plaintiffs conceded that the city of Denver possessed a legitimate interest in animal control as a means to preserve the health and safety of the public, but maintained that the city's chosen means - a pit bull ban enacted twenty years earlier - was no longer rationally related to achieving that interest. ${ }^{106}$ The challengers presented evidence from breeding standards that the prohibited dog breeds made excellent family pets and were not significantly more dangerous than many other non-prohibited breeds. ${ }^{107}$ The district court had granted the city's motion to dismiss, citing older case law from other jurisdictions that upheld similar bans. ${ }^{108}$ The Tenth Circuit reversed, emphasizing that the plaintiff's specific argument was that "although pit

1987 S. CT. REV. 397 (1987).

99 Milnot Co. v. Richardson, 350 F. Supp. 221, 222-23 (S.D. Ill. 1972).

100 Id. at 221.

101 Id. at 224.

102 Carolene, 304 U.S. 144, 149 n.2, 150 n.3.

103 Milnot, 350 F. Supp. at 222-23.

$104 I d$. at 224 ("[T] and judicial upholding of the Filled Milk Act many years ago . . . have long since ceased to exist."). The court relied on Chastleton Corporation v. Sinclair, which is the case that the Carolene Court relied on for the same proposition. Id.; see also Carolene, 304 U.S. at 153; Chastleton Corporation v. Sinclair, 264 U.S. 543, 547-48 (1924).

105 Dias v. City \& Cnty. of Denver, 567 F.3d 1169 (10th Cir. 2009).

106 Id.

107 Id. at 1184.

108 Id. 
bull bans sustained twenty years ago may have been justified by the thenexisting body of knowledge, the state of science in 2009 is such that the bans are no longer rational." 109

One court utilized the changed circumstances doctrine to ferret out an original, illegitimate purpose of a statute. In Santos v. City of Houston, the plaintiff challenged a seventy-year-old Houston ordinance that banned private vans (jitneys) carrying fifteen people or more on public streets. ${ }^{110}$ Since the ban's enactment, a number of virtually identical services had begun to operate in the city - van pools, ride sharing services, air transport vans, and the like. ${ }^{111}$ The government contended that the jitney ban served current objectives of safety and unimpeded traffic flow, an argument that the court found unavailing in light of the many similar vehicles that could freely operate on public streets. ${ }^{112}$ After dismissing as irrational the offered justifications for furthering legitimate purposes, the court examined evidence of the original motivation behind the ban-to eliminate competition against the streetcar industry. ${ }^{113}$ Such a purpose is not only arguably illegitimate, ${ }^{114}$ but also irrelevant, since streetcars had long ceased to operate on Houston's streets. ${ }^{115}$ "[E]ven if the ordinance ever had a purpose, legitimate or not," the court said, "its utility has passed."116

The changed circumstances doctrine is almost necessary when a statute is so old that it is not even possible to find any evidence of its original purpose. In Brown v. Barry, a "shoeshine entrepreneur" began providing showers, training, shoeshine kits, and employment to homeless persons in the District of Columbia. ${ }^{117} \mathrm{He}$ operated successfully and without incident for several years under a general vendor permit. ${ }^{118}$ In a sudden change of course, the District revoked his permit for violating an eighty-three-year-old municipal ordinance, which provided that "no permit shall be issued for a bootblack [shoeshine] stand on public space." ${ }^{119}$ Unable to produce any relevant legislative history for the ordinance, the government speculated that the ban could have been intended to reduce litter or prevent impediments to sidewalk pedestrian traffic. ${ }^{120}$ The court found these

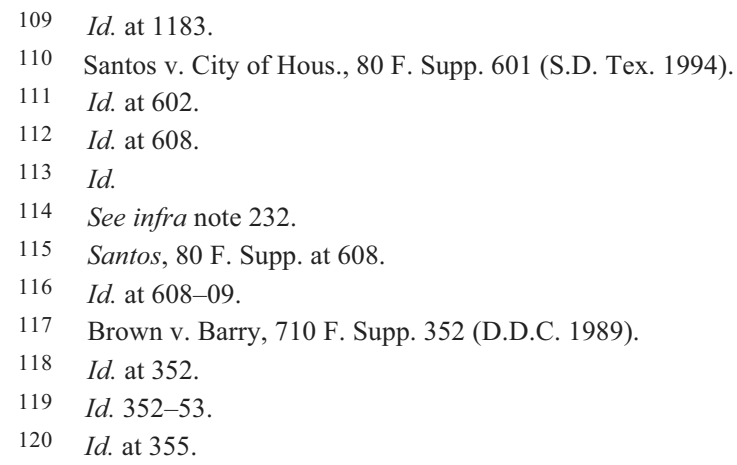


justifications unavailing since there was no evidence that the shoeshines took up more space than larger, permitted vendors such as fruit stands. ${ }^{121}$ The court noted that "the District has not articulated the belief that there is a continuing validity or life to this regulation in the present context." " the lack of any articulable rational basis for distinguishing shoeshines from other vendors, the court found the ordinance unconstitutional. ${ }^{123}$

The Supreme Court has not always been receptive to constitutional challenges based on changed circumstances. In Brotherhood of Locomotive Firemen and Enginemen v. Chicago, Rock Island \& Pacific Railroad, the Court reviewed "full-crew laws," which dictated the size and personnel makeup of train crews. ${ }^{124}$ The Court had upheld the law against challenges when they were first enacted at the beginning of the century, but almost fifty years later, a changed circumstances argument was brought to the table. ${ }^{125}$ The challengers presented considerable evidence that technological advancements and the increasing obsolescence of certain railroad jobs meant that the old laws overestimated the crew size necessary to operate the trains. ${ }^{126}$

The plaintiffs prevailed in the district court, but the Supreme Court did not accept their changed circumstances arguments. The Court noted that the evidence regarding the need for full crews was still mixed or inconclusive and railroad laws had been the subject of disputes and "legislative reevaluation" for many years. ${ }^{127}$ In light of this ongoing political conflict and inconclusive evidence, the Court said, it was inappropriate for the judiciary to intervene and deem the laws outdated. ${ }^{128}$ The district court's findings of fact regarding the law's obsolescence, according to the Court, was an improper usurpation of democratic judgment. ${ }^{129}$ Resolution of ongoing political conflicts, the Court said, may be "fixed only by the people acting through their elected representatives."130

It is important to note that although the Court explicitly rejected the plaintiff's changed circumstances argument in this particular case, the Court did not overrule its earlier changed circumstances cases or indicate that constitutional inquiries must only be limited to the factual circumstances

121 Id.

122 Id.

123 Id. at 356.

124 See Bhd. of Locomotive Firemen \& Enginemen v. Chi., Rock Island \& Pac. R.R., 393 U.S. 129 (1968).

125 Id. at 131.

126 Id. at 135.

127 Id. at 136.

128 Id. at 133-34.

129 Id. at 138.

$130 \quad$ Id. 
that existed at the time of enactment. Thus, Brotherhood might best be viewed as discouraging - but not precluding - the changed circumstances doctrine as defined in Carolene.

Although Carolene's rule regarding changed circumstances was unambiguous, lower courts have been led astray by other language in Carolene's more general discussion about judicial deference to legislative judgment, as well as later, inapposite Supreme Court rational basis review cases. Practical concerns, such as institutional costs and the limited competency of courts to ascertain and weigh facts, have also played a role in some courts' abandonment of the changed circumstances doctrine.

In Murillo v. Bambrick, the Third Circuit held that New Jersey's imposition of trial fees upon individuals undergoing divorces, but not on other civil litigants, did not violate the Equal Protection Clause. ${ }^{131}$ The divorce trial fees had originally served to offset the costs of the special masters used in divorce proceedings. After the special master requirement was abolished and the stated adopted no-fault divorce, the challengers argued that the fees lost any rational relationship to offsetting the costs of divorce proceedings. ${ }^{132}$ The court conducted a standard rational basis review analysis and upheld the statute. ${ }^{133}$

The court declined to adopt a changed circumstances analysis because, it said, "the Supreme Court appears not to have determined definitively whether changed conditions are a relevant consideration." ${ }^{134}$ The Murillo court compared the changed circumstances language from Carolene with language from two of the Supreme Court's rational basis review cases. In Minnesota v. Clover Leaf Creamery, the Court declared, "Where there was evidence before the legislature reasonably supporting the classification, litigants may not procure invalidation of the legislation merely by tendering evidence that the legislature was mistaken." ${ }^{.135}$ And in Lindsley v. Natural Carbonic Gas Co., the Court said that "if any state of facts reasonably can be conceived that would sustain [a statute], the existence of that state of facts at the time the law was enacted must be assumed."136 The Third Circuit interpreted these two statements to preclude a changed circumstances constitutional analysis, but conceded that "[ $\mathrm{t}]$ here may be a role for the courts to play when a statute, rendered manifestly unreasonable by changed conditions, remains in effect for many years without legislative

131 Murillo v. Bambrick, 681 F.2d 898 (3d Cir. 1982).

132 Id. 900-01.

$133 \quad I d$. at 908.

134 Id. at 912 n.27.

135 Minnesota v. Clover Leaf Creamery Co., 449 U.S. 456, 464 (1981).

136 Lindsley v. Nat. Carbonic Gas Co., 220 U.S. 61, 78 (1911). 
actions." $^{, 137}$

The Murillo court also gave a non-legal justification for abandoning the changed circumstances doctrine. It was concerned about institutional costs that the changed circumstances doctrine could impose on the government. ${ }^{138}$ By invalidating laws that were valid when originally enacted, but grounded on assumptions that were later found incorrect, the courts would be effectively imposing an affirmative obligation on the legislature. ${ }^{139}$ To avoid the judicial intervention and invalidation of laws, the legislature would have to "constantly reassess the continuing validity of the factual premises underlying each piece of legislation enacted over the years" in order to discover and correct the alleged error. ${ }^{140}$ In the present case, the court noted, only nine years had passed from the time the statute was enacted and the time of the challenge, which provided little opportunity for the legislature to complete such a process. ${ }^{141}$

The Third Circuit recently confirmed its renouncement of the changed circumstances doctrine in a challenge to Pennsylvania's funeral industry regulations, which date back to $1952 .{ }^{142}$ In Heffner v. Murphy, the plaintiffs sought to invalidate of a number of arcane laws, including a requirement that all funeral homes maintain preparation rooms, and a prohibition on serving food and drinks in funeral homes. ${ }^{143}$ The district court held that some of the regulations were outdated, irrational, and now appeared to serve only economically protectionist purposes. ${ }^{144}$ The Third Circuit reversed, rejecting the lower court's consideration of changed circumstances. ${ }^{145}$ Citing the highly deferential nature of rational basis review, the Third Circuit declared that although "certain provisions of [Pennsylvania's funeral industry law] are antiquated in light of how funeral homes now operate[,] ... [t] hat is not . . . a constitutional flaw."146

137 Id. at 912.

138 Murillo v. Bambrick, 681 F.2d 898, 911 (3d Cir. 1982).

139 Id.

$140 I d$.

141 Id.

142 Heffner v. Murphy, 745 F.3d 56, 62-64 (3d Cir. 2014), cert. denied, 135 S. Ct. 220 (2014).

143 Id.

144 See Heffner v. Murphy, 866 F. Supp. 2d 358, 429 (M.D. Pa. 2012) ("[W]e admonish the [Funeral Board] to apply appropriate focus and craft, or clarify, regulations that appropriately govern the funeral industry in this, the twenty-first century.").

145 Heffner, 745 F.3d at 62.

146 Id. The Supreme Court denied certiorari in Heffner v. Murphy, declining to clarify whether rational basis review requires a court to evaluate the rationality of a law's enforcement under current factual circumstances, or only the factual circumstances that existed at the time the law was enacted-no matter how long ago the law was enacted or how much the factual circumstances have changed since its enactment. See Heffner v. Murphy, 135 S. Ct. 220 (2014) (denying writ of certiorari); Heffner v. Murphy Petition, supra note 17 , at*1. 
The Ninth Circuit also considered the impact of changed circumstances on a Minnesota railroad regulation. ${ }^{147}$ In 1985, the Burlington Railroad Corporation challenged a turn of the century statute that compelled railroads to maintain station houses and staff in any town with a population of one thousand or more. ${ }^{148}$ The court defined the legitimate purpose of the statute as fostering "public convenience and necessity" by ensuring that towns received a minimum level of service. ${ }^{149}$ The railroad argued that the regulation no longer rationally served that interest because many of the duties that had been historically performed by service agents were now computerized and conducted in centralized service centers. Furthermore, Burlington argued, changes in freight practices meant that some of the smaller stations rarely handled any freight at all and did not need the same level of staffing as others. ${ }^{150}$ The court conducted a standard rational basis review analysis and held that, since the population requirements had been updated only sixteen years prior to the challenge, the railroad had not shown that circumstances had changed so drastically that the statute no longer possessed a rational basis. ${ }^{151}$

Citing Carolene, Lindsley, and Clover Leaf, the Ninth Circuit described the Supreme Court as being "ambivalent" about whether changed circumstances could transform a once-rational statute into an irrational law. ${ }^{152}$ Nevertheless, the court took it upon itself to declare that the time of a classification's creation is the appropriate contextual reference point for the purposes of an equal protection rational basis review analysis. ${ }^{153}$

The District Court of the Southern District of New York recently followed the leads of Murillo and Burlington in rejecting the changed circumstances doctrine. In Jones v. Schneiderman, the court evaluated New York State's prohibition of mixed martial arts (MMA) fighting under both equal protection and due process. ${ }^{154}$ New York banned MMA fighting in 1996 on the grounds that it posed significant health and safety risks to the competitors and negatively influenced the public morality and youths of New York. ${ }^{155}$ The plaintiffs argued that significant changes in the rules and

147 Burlington N. R.R. Co. v. Dep’t of Pub. Serv. Reg., 763 F.2d 1106, 1108-09 (9th Cir. 1985).

148 Id. at 1109.

149 Id. at 1110.

$150 \quad I d$. at 1109.

151 Id.

152 Id. at 1111.

153 Id. at 1111 n.3 ("In construing statutory language, a court must ordinarily consider the circumstances at the time of passage, rather than later interpretations or statements of purpose. Where courts have invalidated archaic statutes, there is often an independent constitutional basis for doing so (i.e., a belated recognition that the statutes were unconstitutional as written).") (citations omitted).

154 Jones v. Schneiderman, 888 F. Supp. 2 d 421 (S.D.N.Y. 2012).

155 Id. at 422. 
administration of professional MMA fighting turned a once violent, "anything goes" sport into something far safer and more appropriate for a broader mainstream audience. ${ }^{156}$ At the time of the lawsuit, the athletic commissions of forty-five other states had officially sanctioned MMA fighting, which the plaintiffs argued was proof that the sport was far safer and no longer posed substantial threats to the public welfare. ${ }^{157}$ The court cited to Clover Leaf and held that the prohibition of MMA was both rational at the time it was adopted and rational at the time that it was enforced, despite the substantial discrepancies in the factual circumstances between the two. ${ }^{158}$

Outside of the substantive due process and equal protection context, but still within rational basis review, some litigants have invoked the changed circumstances doctrine to challenge federal criminal drug sentences, alleging that new evidence proves that the justifications underlying the laws were incorrect. Criminal defendants have asserted-so far with no success - equal protection challenges to the federal mandatory minimum sentences under the Anti-Drug Abuse Act, which punish crack cocaine offenses 100 times more severely than powder cocaine offenses. ${ }^{159}$

The Second and Seventh Circuit Courts of Appeals both considered changed circumstances arguments against the mandatory minimum crack offense sentences, but declined to use changed circumstances as a reason to invalidate the laws. In United States v. Then, the Second Circuit rejected a defendant's equal protection challenge to his crack conviction sentence and declined to consider the changed circumstances doctrine. ${ }^{160}$ In a concurrence, Judge Calabresi grappled with the relevance of considerable emerging research that showed crack did not pose a substantially greater threat than cocaine to users or to society, as well as evidence of its profoundly disparate impact on minorities. ${ }^{161}$ Although Calabresi did not believe that the evidence at the time compelled the finding of an equal protection violation, he noted that if the evidence continued to develop, "constitutional arguments that were unavailing in the past may not be

156 Id. at 423-24.

157 New York, which had long been the only state that prohibited MMA, recently lifted the ban. See Damon Martin, New York Legalizes MMA After Nearly 20-Year Ban on the Sport, Fox SPORTS (May 22, 2016, 6:30 PM), www.foxsports.com/ufc/story/ufc-new-york-legalizes-mma-after-nearly-20year-ban-on-the-sport-032216.

158 Schneiderman, 888 F. Supp. 2d at 425.

159 See, e.g., United States v. Then, 56 F.3d 464 (2d Cir. 1995); United States v. Moore, 644 F.3d 553 (7th Cir. 2011).

160 Then, 56 F.3d at 466. The majority expressly disavowed Calabresi's concurrence, which recognized the changed circumstances doctrine.

161 Id. at 468 (Calabresi, J., concurring). 
foreclosed in the future."162 Calabresi cautioned, however, against "courts ... step[ping] in [to] say that what was rational in the past has been made irrational by the passage of time, change of circumstances, or the availability of new knowledge." 163 Accounting for changed circumstances, Calabresi suggested, could lead to "hazardous" line-drawing in judicial decisions that should remain in the purview of the legislature. ${ }^{164}$

Since Then, few courts have embraced Calabresi's prediction. ${ }^{165}$ Almost twenty years later, in United States v. Moore, the Seventh Circuit noted that the challenger's evidence - a series of Sentencing Commission reports - indeed undermined many of Congress's prior assumptions that crack cocaine was more addictive, more harmful, and caused more violence than cocaine in the powder form. ${ }^{166}$ However, the same reports also contained findings indicating that crack was still at least somewhat more dangerous than powder cocaine. ${ }^{167}$ Citing again to Carolene, the court determined that the factual evidence about crack and cocaine sentencing remains "at least debatable," and the ultimate determination must be left to Congress. ${ }^{168}$ Although the court rejected Moore's arguments, it acknowledged that a challenge based on changed circumstances could be a legitimate avenue for a constitutional attack. ${ }^{169}$

$162 I d$. at 467. Calabresi noted two relevant sources of changing factual evidence. First, the Sentencing Commission had conducted an investigation and found little evidence that crack was substantially more dangerous than cocaine. It also recommended that Congress eliminate the differential treatment of crack and cocaine. Second, statistical research revealed that the sentencing ratio disparately impacted minorities, who comprised the majority of crack users and distributors. Id. at 467-68.

163 Id. at 468.

164 Id. at 466-69. Calabresi also noted some interesting international comparisons to changed circumstances, and suggested that even if American courts do not immediately invalidate laws on the basis of changed circumstances, they might be able to provide notice when a statute or regulation appears to be approaching unconstitutionality. In Germany, for example, the Constitutional Court does not immediately strike down an outdated law that appears to be unconstitutional. Instead, it declares that the law is approaching unconstitutionality because of changed circumstances. This serves to put parliament on notice and allow time for review and reconsideration of the legislation before the Court completely nullifies it. $I d$.

165 See, e.g., United States v. Moore, 644 F.3d 553 (7th Cir. 2011). But see Kimbrough v. United States, 552 U.S. 85, 96-97 (2008) (Under United States v. Booker, 543 U.S. 220 (2005), a sentencing judge was permitted to deviate from 100-1 sentencing guidelines based on a "need to avoid unwarranted sentence disparities.").

$\begin{array}{ll}166 & I d . \text { at } 556-57 . \\ 167 & I d . \text { at } 557 . \\ 168 & I d . \text { at } 556 .\end{array}$

169 Id. More recently, plaintiffs have begun to wage challenges against the federal government's classification of marijuana as a Schedule I drug, citing Carolene and presenting evidence to disprove Congress's finding from forty-five years ago that marijuana possesses no medicinal benefit. See Larsen, supra note 19, at 96. In addition to presenting new facts about current scientific understandings of marijuana's effects on the body and medical usefulness, litigants have also argued that the federal government's purpose is greatly diminished as states begin to legalize the drug. $I d$. 


\section{The Changed Circumstances Doctrine Beyond Rational Basis Review}

In equal protection cases involving heightened levels of scrutiny, the Supreme Court routinely considers the impact of changed circumstances on the constitutionality of laws. In evaluating a race-conscious admissions policy in Grutter v. Bollinger, the Supreme Court explicitly recognized that there would be some future point at which the policy would no longer pass constitutional muster. ${ }^{170}$ If race-conscious admissions policies are successful in furthering the compelling interest of increasing diversity in higher education, it logically follows that diversity will eventually, hopefully, reach some intended or desirable level. When it does, the same policies would no longer be necessary for furthering the same purpose and would no longer be able to survive the strict scrutiny standard. ${ }^{17}$

The First Amendment has also proven fertile ground for challengers to allege unconstitutionality on the basis of changed factual circumstances. The changed circumstances doctrine has not served as an analytical tool in any of the Supreme Court's majority opinions; however, the significance of factual change over time was squarely addressed by Justice Thomas, who recently discussed the issue in a dissent ${ }^{172}$ and concurrence. ${ }^{173}$ Changed circumstances were also integral in a First Amendment decision from the Second Circuit. ${ }^{174}$

In FCC v. Fox Television, the Court heard a challenge regarding agency regulations from the Federal Communication Commission (FCC). ${ }^{175}$ In the 1950s, the FCC promulgated various regulations in furtherance of the "fairness doctrine," requiring broadcasters to provide equivalent on-air exposure for political candidates and allow for equal discussion from all sides of a political or public issue. ${ }^{176}$ The Supreme Court upheld the regulations against a First Amendment challenge in Red Lion Broadcasting

170 Grutter v. Bollinger, 539 U.S. 306, 341-42 (2003) ("We are mindful . . . that "[a] core purpose of the Fourteenth Amendment was to do away with all governmentally imposed discrimination based on race.' Accordingly, race-conscious admissions policies must be limited in time.") (citations omitted).

171 Id. at 343 ("It has been 25 years since Justice Powell first approved the use of race to further an interest in student body diversity in the context of public higher education. Since that time, the number of minority applicants with high grades and test scores has indeed increased. We expect that 25 years from now, the use of racial preferences will no longer be necessary to further the interest approved today."). The Court stressed the delicate balance between the government's interest and the means employed in the admissions policy, noting that "racial classifications, however compelling their goals, are potentially so dangerous that they may be employed no more broadly than the interest demands." Id. at 342. This suggests that even minor shifts in factual circumstances could impact constitutionality.

172 See FCC v. Fox Television Stations, Inc., 556 U.S. 502, 530-35 (2009) (Thomas, J., dissenting).

173 See Ashcroft v. Free Speech Coal., 535 U.S. 243, 259-60 (2002) (Thomas, J., concurring).

174 See TJS of New York, Inc. v. Smithtown, 598 F.3d 17 (2d Cir. 2010).

175 Fox Television, 556 U.S. at 505.

176 Red Lion Broad. Co. v. FCC, 398 U.S. 367 (1969). 
v. FCC, citing the scarcity of the broadcast spectrum and the need for the government to "control ... the cacophony of competing voices" as warranting the intrusion on free speech and expression. ${ }^{177}$ Since that time, the FCC has invoked spectrum scarcity to justify a wide array of broadcast regulations well beyond the fairness doctrine. ${ }^{178}$ Basing a constitutional rule on the nature of a broadcast medium practically invites challenges based on changed circumstances. Litigants have raised several challenges citing the anachronism of the spectrum scarcity rationale but the Court has yet to overrule Red Lion. ${ }^{179}$

Fox Television was not decided on constitutional grounds, but in his dissent, Justice Thomas expressed strong disagreement with Red Lion's use of a "set of transitory facts" to define the lenient First Amendment protections for broadcasters. ${ }^{180}$ He noted that even if Red Lion applied an appropriate constitutional standard, the factual assumptions underlying the rule had been "eviscerated" by tremendous technological advances that had since developed. ${ }^{181}$ Television and radio are now supplemented by seemingly endless options over cable, satellite, and the internet. "These dramatic changes in factual circumstances," Thomas said, "might well support a departure from precedent under the prevailing approach to stare decisis. $" 182$

Justice Thomas also considered changed circumstances in his concurrence in Ashcroft v. Free Speech Coalition. ${ }^{183}$ The majority opinion invalidated a federal prohibition on "virtual child pornography," which is sexually explicit material that appears to depict minors, but is produced using youthful looking adults or computer generated imagery, rather than actual children. ${ }^{184}$ Justice Thomas agreed that the ban could not be sustained under the First Amendment, but found one of the government's arguments persuasive: Without the ban, people who possess and distributed

177 Id. at 376.

178 Larsen, supra note 19, at 89.

179 See, e.g., Brief of Respondents NBC Universal, Inc. et al. at 32-38, FCC v. Fox Television Stations, Inc., 556 U.S. 502 (2009) (No. 07-582), 2008 WL 3153438, at*32-38; Petition for Writ of Certiorari at 14-20, Minority Television Project, Inc. v. FCC, 134 S. Ct. 2874 (2014) (No. 13-1124), 2014 WL 1090035, at*14-20; Petition for Writ of Certiorari at 16-23, Media Gen., Inc. v. FCC, 133 S. Ct. 63 (2011) (No. 11-691), 2011 WL 6069620, at*16-23; see also Thomas W. Hazlett et al., The Overly Active Corpse of Red Lion, 9 Nw. J. TECH. \& INTELL. Prop. 51, 53 (2010).

180 Fox Television, 556 U.S. at 530 (Thomas, J., dissenting) ("Constitutional rights are enshrined with the scope they were understood to have when the people adopted them, whether or not future legislatures or (yes) even future judges think that scope too broad.") (quoting Dist. of Colum. v. Heller, 554 U.S. 570, 635 (2008)) .

181 Id. at 533.

182 Id. at 534 (citing Planned Parenthood of Se. Pa. v. Casey, 505 U.S. 833, 854-63 (1992)).

183 Ashcroft v. Free Speech Coal., 535 U.S. 243, 259-60 (2002) (Thomas, J., concurring).

184 Id. at $239-40$. 
actual pornographic depictions of children might be able to evade prosecution by claiming that the depictions are computer generated. ${ }^{185}$ At the time, there was no evidence that this had ever occurred and computer generated images of children were still readily distinguishable from the real thing. ${ }^{186}$ Thomas speculated, however, that if technology ever evolved to a point where it became impossible to distinguish virtual from actual child pornography, the government's interests in ensuring successful prosecution of child pornographers might justify a future restriction on virtual child pornography. ${ }^{187}$ Thomas suggested the inverse of the typical changed circumstances case- that an unconstitutional government action could eventually cross the threshold into constitutionality.

Another First Amendment doctrine susceptible to the effects of changed factual circumstances is the one governing the regulation of adultoriented businesses. ${ }^{188}$ Under City of Renton v. Playtime Theatres, local governments may enact zoning ordinances that restrict the locations of adult businesses in order to protect the public against detrimental "secondary effects" (e.g., drug use, crime, and prostitution), but not as a way to suppress that form of expression. ${ }^{189}$ Thus, if these substantial interests are served, the ordinance will comport with the First Amendment as long as it "allows for reasonable alternative avenues of communication." 190 In adultoriented business cases, the reasonable alternative avenues inquiry typically entails an assessment of other locations in the town where an adult-oriented business could be located. ${ }^{191}$

In TJS of New York v. Smithtown, the government argued that an ordinance should be deemed constitutionally valid as long as it provided reasonable alternative avenues at the time of enactment, rather than at the time of the challenge. ${ }^{192}$ In 2002, TJS purchased an existing adult entertainment store on a location that was grandfathered under a 1994 ordinance that would have otherwise prohibited it. ${ }^{193}$ TJS continued to operate an adult business at the location and the town sought an order of closure. ${ }^{194}$ The Second Circuit, led by Judge Calabresi, held that courts

185 Id. at 259.

186 Id.

$187 I d$.

188 See generally Peter T. Cavallaro, Beneath Oceans, Airstrips, and Sports Stadiums: Negative Solution to the “Alternative Avenues" Time Frame Debate, 23 CORNELL J.L. \& PUB. POL'Y 487 (2013).

189 City of Renton v. Playtime Theatres, Inc., 475 U.S. 41, 46-48 (1986).

190 Id. at 50.

191 TJS of New York, Inc. v. Smithtown, 598 F.3d 17, 21 (2d Cir. 2010).

192 Id. at 22.

193 Id. at 19.

194 Id. at 20. There had been ongoing First Amendment litigation with the previous owners of the location. Id. 
must consider the adequacy of alternative avenues at the time the ordinance is challenged, not at the time the ordinance was enacted. ${ }^{195}$ Judge Calabresi warned what could result from a contrary interpretation:

If the only relevant question were whether an ordinance provided adequate alternatives on the day of its passage, any law that did so would thereafter be immune from First Amendment challenge. And speech that the Supreme Court has held to be protected by that Amendment would be silenced. ${ }^{196}$

This case in particular illustrates how the changed circumstances doctrine enables the courts to preserve individual rights in perpetuity. Without it, constitutional rights could be essentially limited in time by factual conditions that no longer exist.

The final case in this section, Shelby County v. Holder, is the Supreme Court's most recent and clearest articulation of the changed circumstances doctrine. ${ }^{197}$ It does not fit neatly with any of the other changed circumstances cases discussed above-it is the only Fifteenth Amendment case and the standard of review the Court employed is debatable. But it makes it abundantly clear that the Court views constitutional analysis to require consideration of the contextual facts and circumstances that exist when the law is challenged, not those that existed when the law was enacted.

Justice Kennedy was perhaps stating the obvious when he said during the Shelby County oral arguments, "[T]imes change."198 But that simple proposition became the Court's primary justification for striking down the preclearance coverage requirement in the Voting Rights Act of $1965 .{ }^{199}$ The provision at issue was a formula used to determine which states and counties were "covered" jurisdictions required to obtain approval from the federal government before passing voting laws. ${ }^{200}$ The Court had upheld the provision shortly after enactment. ${ }^{201}$

195 Id. at 22-23; see also Cnty. of DuPage v. Lake St. Spa, Inc., 916 N.E.2d 1240 (Ill. App. Ct. 2009). The court noted that its holding could be in conflict with two other cases, but maintained that it had reached the proper result. Id. at 25; see also Daytona Grand, Inc. v. Daytona Beach, 490 F.3d 860 (11th Cir. 2007); Bigg Wolf Discount Video Movie Sales, Inc. v. Montgomery Cnty., 256 F. Supp. 2d 385 (D. Md. 2003).

196 TJS of New York, 598 F.3d at 26.

197 See Shelby Cnty. v. Holder, 133 S. Ct. 2612 (2013).

198 Oral Argument at 38:41, Shelby Cnty. v. Holder, 133 S. Ct. 2612 (2013) (No. 12-96), www.oyez.org/cases/2012/12-96.

199 See Shelby Cnty., 133 S. Ct. at 2624-31.

200 Id. at 2619-20.

201 South Carolina v. Katzenbach, 383 U.S. 301, 330 (1966). 
The "extraordinary" ${ }^{202}$ measures, drafted to expire after five years, were enacted to combat blatant and widespread minority voter disenfranchisement throughout the South. ${ }^{203}$ Over forty years later, they remained in place and had become even more stringent. ${ }^{204}$ But the objective facts demonstrated that the minority voting rates had significantly improved over time, minority representation in political offices increased, and that the states no longer engaged in the improper practices that the law was intended to prevent. ${ }^{205}$ Because it was based on "decades-old data" and "eradicated practices," the Court found that the law simply no longer made sense in light of existing conditions. ${ }^{206}$ "Current burdens," the Court declared, "must be justified by current needs." 207

The Court's terminology suggests that it was applying rational basis review, which was the standard the Court used to uphold the law in $1966 .{ }^{208}$ But the opinion clearly did not exhibit the level of legislative deference that is characteristic of rational basis review. ${ }^{209}$ This could suggest that the Court is willing to scrutinize the rationality of a law a little more carefully when it is particularly old and outdated.

The Court's holding, though deemed virtually catastrophic by the media, ${ }^{210}$ was in fact rather modest. ${ }^{211}$ By relying only on the changed

202 Although the provision contravened fundamental principles of federalism, the measures were deemed necessary to address entrenched racial discrimination in voting. Shelby Cnty., 133 S. Ct. at 2618.

203 Id. at 2620.

204 Id.

205 Id. at $2628-29$.

206 Id. at 2630.

207 Id. (quotations omitted).

208 See id. at 2629 ("Viewing the preclearance requirements as targeting [second-generational barriers] simply highlights the irrationality of continued reliance on the $\S 4$ coverage formula ...."); id. at 2630-31 ("It would have been irrational for Congress to distinguish between States in such a fundamental way based on 40-year-old data, when today's statistics tell an entirely different story. And it would have been irrational to base coverage on the use of voting tests 40 years ago, when such tests have been illegal since that time. But that is exactly what Congress has done."); Id. at 2625 ("We therefore concluded that "the coverage formula [was] rational in both practice and theory."') (quoting South Carolina v. Katzenbach, 383 U.S. 301, 330 (1966)).

209 See Larsen, supra note 19, at 111 (“This isn't your mother's rationality review.").

210 See, e.g., Dana Liebelson, The Supreme Court Gutted the Voting Rights Act. What Happened Next in These 8 States Will Not Shock You, Mother Jones (Apr. 8, 2014, 6:00 AM), www.motherjones.com/politics/2014/04/republican-voting-rights-supreme-court-id; Adam Liptak, Supreme Court Invalidates Key Part of Voting Rights Act, N.Y. TIMES (June 25, 2013), www.nytimes.com/ 2013/06/26/us/supreme-court-ruling.html? r=0.

211 Nathaniel Persily \& Thomas Mann, Brookings Inst., Shelby County V. Holder AND THE FUtURE OF THE VOTING Rights ACT 5 (Aug. 2013), www.brookings.edu/ /media/research/files/ papers/2013/08/09-shelby-v-holder-policy-mann/persily_mann_shelby-county-v-holder-policy-brief_v9.pdf. The Court evaluated a similar case six years earlier. See Nw. Austin Mun. Util. Dist. No. One v. Holder, 557 U.S. 193 (2009). In Northwest Austin, the Court employed constitutional avoidance, resolving the issue on statutory grounds, but "expressed serious doubts about the Act's continued constitutionality." Shelby Cnty., 133 S. Ct. at 2621. 
factual circumstances to find that the preclearance requirement had crossed from constitutionality to unconstitutionality, the Court left for another day far more complex issues - namely the scope of Congress's power under the Fifteenth Amendment. ${ }^{212}$ Congress is now limited by Shelby County only from utilizing the same outdated preclearance formula but not from enacting law under the Fifteenth Amendment. ${ }^{213}$ If Congress determines that some degree of federal oversight is still required for certain jurisdictions, it may attempt to reconfigure the Voting Rights Act accordingly.

In addition to clearly demonstrating that the Supreme Court endorses, at least in one context, a time-of-challenge rather than time-of-enactment approach in evaluating a law's constitutionality, Shelby County provides invaluable guidance from the Supreme Court as to how the changed circumstances doctrine operates in practice.

\section{PRESERVING THE CHANGED CIRCUMSTANCES DOCTRINE AND PROTECTING ECONOMIC LIBERTY}

The Supreme Court's command in Carolene makes clear that the constitutionality of a law must be evaluated with regard to the facts that exist at the time the law is challenged; not the facts that existed when the law was enacted. This makes sense. If an old law impedes a constitutional right today, the government should not be able to justify it with the reasons that only existed long ago. Although this fundamental principle courses through many areas of constitutional jurisprudence, a number of lower courts have failed to adhere to it when reviewing challenges within the most expansive category of constitutional cases - those that apply rational basis review. The changed circumstances doctrine is, and should remain, a core principle of rational basis review in all areas of constitutional law. It could prove particularly beneficial for economic liberty by creating a meaningful judicial limit on the government's power to enforce economic regulations after their utility has passed.

In the seventy-eight years since Carolene, the Court never explicitly overruled its dictate about changed factual circumstances. ${ }^{214}$ The Court has decided a number of rational basis review cases but all have involved challenges to the constitutionality of recently enacted laws, giving no opportunity for the Court to rule on the specific question raised by changed

212 See Shelby Cnty., 133 S. Ct. at 2631; see generally Richard L. Hasen, Shelby County and the Illusion of Minimalism, 22 WM. \& MARY BILL RTS. J. 713 (2014).

213 Shelby Cnty., 133 S. Ct. at 2631.

214 Heffner v. Murphy Petition, supra note 17, at *14. 
factual circumstances. ${ }^{215}$ As a result of a lack of guidance from the Supreme Court, there is conflict amongst the lower courts over whether the changed circumstances doctrine is a part of rational basis review. ${ }^{216}$ There is also inconsistency between how rational basis review and heightened scrutiny levels are applied. ${ }^{217}$ The Supreme Court should clearly reaffirm the changed circumstances doctrine for rational basis review in order to resolve these discrepancies. Until it does, the lower courts should employ the changed circumstances doctrine in rational basis review cases because it is the correct approach under prevailing Supreme Court jurisprudence.

The primary justification that courts have cited for rejecting the changed circumstances doctrine is its perceived conflict with the Court's other rational basis review cases, which counsel almost unwavering judicial deference to legislative choices. ${ }^{218}$ It is understandable, then, that lower courts would hesitate to step in and invalidate even the most antiquated and seemingly obsolete laws - especially economic regulations-given the Court's strong emphasis on judicial deference and its apparent disinterest in meaningfully protecting economic liberties. ${ }^{219}$

Carolene's principle is consistently reflected throughout the Court's constitutional jurisprudence, including rational basis review cases. ${ }^{220}$ But, as noted above, all of the Supreme Court's rational basis review cases since Carolene involved recent legislative enactments. ${ }^{221}$ Thus, the Court's instructions regarding deference were delivered when there were at least relatively contemporaneous legislative decisions on the line and the judiciary risked infringing on the currently acting legislature. This concern declines significantly when the legislative decisions were made by a legislature long ago and based on the factual circumstances relevant to the legislative action at that time. Principles of judicial deference instruct courts

215 Id. Shelby County could be viewed as an exception to this; however, it does not apply the standard two-part rational basis review analysis. See supra notes 208-09 and accompanying text.

216 Compare Heffner v. Murphy, 745 F.3d 56, 62 (3d Cir. 2014), cert. denied, 135 S. Ct. 220 (2014), Burlington N. R.R. Co. v. Dep’t of Pub. Serv. Reg., 763 F.2d 1106 (9th Cir. 1985), Murillo v. Bambrick, 681 F.2d 898 (3d Cir. 1982), and Jones v. Schneiderman, 888 F. Supp. 2d 421 (S.D.N.Y. 2012), with Dias v. City \& Cnty. of Denver, 567 F.3d 1169 (10th Cir. 2009), Santos v. City of Houston, 80 F. Supp. 601 (S.D. Tex. 1994), and Milnot Co. v. Richardson, 350 F. Supp. 221 (S.D. Ill. 1972). See also discussion supra pages 505-07. Scholars also disagree over whether the changed circumstances doctrine should apply, and in which types of cases. See Larsen, supra note 19 (arguing that changed circumstances should only be considered in heightened scrutiny); Ponomarenko, supra note 19 (arguing that changed circumstances should be considered for substance-based tests, but that they are largely irrelevant for motives-based tests); Williamson, supra note 19 (arguing that the changed circumstances doctrine should be extended to equal protection rational basis review cases).

217 See discussion supra pages 518-23.

218 See discussion supra pages 499-506.

219 Id.

220 See discussion supra pages 518-23.

221 See supra note 14 and accompanying text. 
to respect the role and judgment of the legislature, but not to turn a blind eye to an irrational law that no longer has factual grounding in the modern world.

What this means is that reliance on some of the Court's more recent rational basis review jurisprudence is misplaced. For example, the courts in Murillo, Burlington, and Schneiderman all relied on Clover Leaf Creamery to support their rejections of the changed circumstances doctrine. ${ }^{222}$ In Clover Leaf Creamery, however, the Supreme Court's primary concern was that the evidence and research underlying the legislation at issue wasciting Carolene- "at least debatable.",223 Rational basis review jurisprudence has been clear that in such cases the courts must exercise restraint and defer to the legislature's choices. ${ }^{224}$ But the changed circumstances doctrine may not apply when the rationality of a law is still genuinely debatable. A changed circumstances argument specifically asserts that, even though the law had a rational basis when first enacted, under current facts and circumstances, no rational basis remains-the law's rationality is no longer debatable.

Constitutional laws do not necessarily remain constitutional forever. Those whose rights are impeded by outdated laws must be able to seek recourse from the judiciary when such laws become unconstitutional. Completely eliminating the changed circumstances doctrine could lead to absurd results: An outdated law that would be found unconstitutional if enacted today could nonetheless be lawfully enforced simply because it was constitutional at the time of its passage. This cannot be a reasonable interpretation of the Supreme Court's constitutional jurisprudence. Widespread application of the changed circumstances doctrine, on the other hand, would help to promote consistency and predictability because challenged regulations would be evaluated in every case with regard to the contemporaneous factual circumstances.

Non-legal arguments against the changed circumstances doctrine are also unavailing. For example, the Murillo court's concerns about imposing high institutional costs on the legislature are a straw man. The court assumes that, if the changed circumstances doctrine were commonplace, the legislature's most likely response would be to undertake "painstaking effort[s]" to review and update old laws in order to avoid judicial intervention. ${ }^{225}$ But that is unlikely. Changed circumstances challenges can only be successfully waged against outdated laws that continue to be

223 United States v. Carolene Prods. Co., 304 U.S. 144, 154 (1938).

224 See discussion supra pages 499-506.

225 Murillo v. Bambrick, 681 F.2d 898, 911 (3d Cir. 1982). 
enforced after becoming irrational. Thus, the proportion of laws that would be invalidated in a given year would most likely be relatively small. Therefore, a legislature would have virtually no incentive to scour the books just so they can preemptively avoid the occasional judicial invalidation of a law.

A legislature would certainly need to expend resources to review a law in light of the contemporaneous facts when a person files a claim alleging changed circumstances. But this is simply the consequence of judicial review and would not seem to increase the institutional costs beyond what the legislature should otherwise expect. In fact, the review process for everyone involved - challenger, government, and court-might be considerably less burdensome because everyone spared trying to ascertain elusive factual conditions from the past or arcane legislative histories. In any event, legislators might have little investment in these outdated laws, could be happy to see them go, and would be unlikely to waste the time or effort on amending them. Even if the changed circumstances doctrine could lead to some increased institutional costs for the legislature, this hardly seems a strong reason to contravene an established and valuable principle of constitutional analysis.

As a concluding observation, one positive effect of the changed circumstances doctrine is that it could enhance judicial protections of economic liberty. The current state of rational basis review and the Court's disfavored treatment of economic liberty are not only contrary to the constitutional framers' intent and purpose, ${ }^{226}$ they can also lead to extensive negative consequences. ${ }^{227}$ As lower courts and state courts of last resort demonstrate a greater willingness to subject economic regulations to genuine factual scrutiny under rational basis review, ${ }^{228}$ the changed circumstances doctrine could prove an important judicial tool to eliminate arcane regulations that no longer comport with the Constitution.

226 See generally Timothy SAndefur, The Conscience of the Constitution: The DeClaRATION OF INDEPENDENCE AND THE Right TO LiBeRTY (2014); Barnett, supra note 1; Foley, supra note 1; James W. Ely, Jr., Economic Liberties and the Original Meaning of the Constitution, 45 SAN Diego L. REV. 673 (2008); Neily, supra note 1; Timothy Sandefur, The Right to Earn a Living, supra note 1.

227 See generally James M. Buchanan And Robert D. Tollison, The Theory of Public Cholce (1972); Randy E. Barnett, Does the Constitution Protect Economic Liberty?, 35 HARV. J.L. \& PuB. Pol'y 5 (2012); Anne O. Krueger, The Political Economy of the Rent-Seeking Society, 64 AM. ECon. Rev. 291, 291-303 (1974); Paul J. Larkin, Jr., Public Choice Theory and Occupational Licensing, 39 HARV. J.L. \& PUB. POL’Y 209, 216-22 (2016); Raynor, supra note 1; Steven M. Simpson, Judicial Abdication and the Rise of Special Interests, 6 CHAP. L. REV. 173, 176-77 (2003); Brief for Todd J. Zywicki, as Amicus Curiae Supporting Plaintiffs-Appellees, St. Joseph Abbey v. Castille, 712 F.3d 215 (5th Cir. 2013) (No. 11-30756), 2011 WL 6779085.

228 See supra pages 505-06. 
The issues that the changed circumstances doctrine addresses are particularly salient to economic regulation. Economic laws are present in virtually every facet of our lives - the vast majority of occupations, industries, products, and markets are subject to some degree of regulation from one or more levels of government. ${ }^{229}$ Given the remarkable rate of human innovation, social change, and the malleability of markets, economic regulations are uniquely susceptible to obsolescence. ${ }^{230}$ The consequences of an overabundance of arcane and cumbersome regulation can be highly detrimental-hindering economic growth, for example, or disparately limiting economic opportunities for poor and minority populations. ${ }^{231}$ Moreover, economic regulation is uniquely prone to abuses-embedded, politically-connected businesses encouraging government regulation as a shield against competition under a guise of protecting public health, safety, and welfare. ${ }^{232}$

229 See, e.g., Larkin, supra note 227; Simpson, supra note 227; DICK M. CARPENTER II ET AL., INST. FOR JUSTICE, LICENSE TO WORK: A NATIONAL STUDY OF BURDENS FROM OCCUPATIONAL LICENSING 6-7 (2012), www.ij.org/wp-content/uploads/2015/04/licensetowork1.pdf; Michael D. Tanner, Too Many Laws, Too Much Regulation, NAT'L REV. (Mar. 2, 2016, 4:00 AM), www.national review.com/article/432181/regulation-versus-freedom; Over-Regulated America, ECONOMIST (Feb. 18, 2012), www.economist.com/node/21547789.

230 See, e.g., Christopher Koopman \& Patrick McLaughlin, When Technology Makes Regulations Obsolete, MERCATUS CTR. (May 11, 2016), www.mercatus.org/expert_commentary/when-technologymakes-regulations-obsolete; Phillip K. Howard, How Stupid, Redundant, Obsolete Laws Are Paralyzing Us, FisCAL Times: ReBoot AmericA (Feb. 24, 2015), http://rebootamerica.thefiscaltimes.com/index. $\mathrm{php} /$ how-stupid-redundant-obsolete-laws-are-paralyzing-us.

231 See, e.g., John W. Dawson \& John J. Seater, Federal Regulation and Aggregate Economic Growth, 18 J. ECON. GROwTH 137 (2013) (growth of federal regulation over the past sixty years decreased economic growth by an average two percent per year); Robert G. McCloskey, Economic Due Process and the Supreme Court: An Exhumation and Reburial, 1962 S. Ct. 34, 50 (1962); Raynor, supra note 1, at 1094-95; Scott Beyer, How San Francisco's Progressive Policies Are Hurting the Poor, REASON (Nov. 9, 2014), www.reason.com/archives/2014/11/09/how-san-franciscos-progressive-pol icies.

232 A circuit split has emerged over the last decade and a half regarding whether naked protectionism, with nothing more, qualifies as a legitimate government purpose for economic regulation. Compare Sensational Smiles, LLC v. Mullen, 793 F.3d 281 (2d Cir. 2015), and Powers v. Harris, 379 F.3d 1208 (10th Cir. 2004), with St. Joseph Abbey v. Castille, 712 F.3d 215 (5th Cir. 2013), and Craigmiles v. Giles, 312 F.3d 220 (6th Cir. 2002); see also Minnesota v. Clover Leaf Creamery Co., 449 U.S. 456, 471 (1981) (under the Commerce Clause, "[i]f a state law purporting to promote environmental purposes is in reality 'simple economic protectionism,' [the Court has] applied a 'virtually per se rule of invalidity"'). In economic regulation cases, as noted above, the changed circumstances doctrine will typically focus on the objective facts and their bearing on the means-end relationship between a law and the government's purpose. But if pure economic protectionism, without any associated public health, safety, or welfare benefits, is a legitimate government purpose, then it seems unlikely that economic regulation could ever be held unconstitutional. Almost all laws could be justified as means to further protectionist purposes. Under this scenario, the objective facts no longer matter, much less whether those facts have changed. For different perspectives on the circuit split, see generally Evan Bernick, Towards a Consistent Economic Liberty Jurisprudence, 23 GEO. MASON L. ReV. 479 (2016); Katherine M. Rudish, Unearthing the Public Interest: Recognizing Intrastate Economic Protectionism as a Legitimate Government Interest, 81 FORDHAM L. REV. 1485 (2012). 
Broad grants of government power to regulate economic activitieseven those originally intended to serve the public health, safety, and welfare - can, over time, begin to serve primarily protectionist ends. Judge Brown of the United States Court of Appeals for the District of Columbia expressed great concern about this in her concurrence in Hettinga v. United States. ${ }^{233}$ The majority upheld certain provisions under the Milk Regulatory Equity Act (MREA), which imposed complex price controls upon milk producers and handlers and required both to pay into a redistributive fund. ${ }^{234}$ One enterprising dairyman found a way to sell gallons of milk for twenty cents less than his competitors by taking advantage of a producerhandler exemption. ${ }^{235}$ Dairy lobbyists successfully petitioned to have the exemption eliminated. ${ }^{236}$ The court upheld the revised regulations under rational basis review. ${ }^{237}$

Judge Brown lamented that the court was bound to reach the conclusion that it did, explaining that the Supreme Court had "abdicated its constitutional duty to protect economic rights" in its development of rational basis review and relegation of economic liberty to a "lower echelon of constitutional protection." ${ }^{238}$ Judge Brown suggested that once-legitimate interests underlying the enactment of the MREA — correcting "disorderly market conduct" after the Depression-no longer existed, and the only remaining purpose was to enrich the dairy industry at the expense of consumers. ${ }^{239}$ The exact situation in Hettinga would not have presented an ideal opportunity for challenge under the changed circumstances doctrinethe challenged government action was a recent legislative enactment to close the producer-handler exemption. But there is certainly a changed circumstances argument to be made that the broader MREA regulatory scheme places "current burdens" on economic liberty that may very well not be "justified by current needs."

233 See Hettinga v. United States, 677 F.3d 471, 480-83 (D.C. Cir. 2012) (Brown, J., concurring).

234 Id. at 475 (majority opinion).

235 Id.

236 Id.

237 Id.

238 Id. at 482 (Brown, J., concurring) ("Rational basis review means property is at the mercy of the pillagers. The constitutional guarantee of liberty deserves more respect-a lot more.").

239 Id. (Brown, J., concurring) ("To be sure, the economic climate [during the Depression] was truly dire, but 78 years later, the same tired trope about 'disorderly market conduct' is still extant.") (citing Alto Dairy v. Veneman, 336 F.3d 560, 562 (7th Cir. 2003)). Judge Brown also hinted at the role of changed circumstances in Edwards v. District of Columbia, a First Amendment challenge to the licensing requirements for tour guides in the District of Columbia. Stating that "reliance on decades-old evidence says nothing of the present state of affairs," Judge Brown discussed modern circumstances, which include crowd-sourcing review operations such as Yelp and TripAdvisor, that undermined the District's argument that licensing was necessary to protect the public from unscrupulous tour guides who fleece unsuspecting tourists. See Edwards v. District of Columbia, 755 F.3d 996 (D.C. Cir. 2014). 
The impact that the changed circumstances doctrine could have in terms of scaling back judicial deference or helping to restore economic liberty is modest - it is little more than rational basis review with nibble. As Shelby County illustrates, the changed circumstances doctrine is a minimalist approach. It does not require altering the rational basis standard or changing the constitutional status of economic liberties. And the class of claims to which the changed circumstances doctrine might apply is relatively narrow. But for those whose economic liberties are impeded by cumbersome and outdated economic regulations, the changed circumstances doctrine could provide a small, but meaningful opportunity to wage effective challenges in court to vindicate their constitutional rights. 